\title{
Middle/late Miocene hoplocetine sperm whale remains (Odontoceti: Physeteridae) of North Germany with an emended classification of the Hoplocetinae
}

\author{
Oliver Hampe* \\ Museum für Naturkunde der Humboldt-Universität zu Berlin, Invalidenstraße 43, D-10115 Berlin
}

Received 29 March 2005, accepted 19 September 2005

Published online 01. 02. 2006

With 20 figures and 3 tables

Key words: fossil Physeteridae, Hoplocetinae, Miocene, distribution, dentition, North Germany.

\begin{abstract}
Hoplocetus ritzi n. sp. is a new hoplocetine physeterid from the Bolboforma fragori/subfragoris Zone of the middle/late Miocene mica-clay of Groß Pampau in Schleswig-Holstein, North Germany. The Hoplocetinae are known from the early Miocene to the Pliocene. Comparative studies of cranial characters and tooth morphology allow an emended diagnosis of the Hoplocetinae Cabrera, 1926. Four genera, Diaphorocetus, Idiorophus, Scaldicetus, and Hoplocetus are included in this subfamily. The pattern of functional tooth wear deduced from the described Hoplocetus ritzi n. sp. remains is reminescent of that known from Orcinus orca. The hoplocetine physeterids possibly occupied the killer whale niche before the killer whales appeared during the middle Pliocene.
\end{abstract}

Schlüsselwörter: fossile Physeteridae, Hoplocetinae, Miozän, Verbreitung, Bezahnung, Norddeutschland.

\section{Zusammenfassung}

Mit Hoplocetus ritzi n. sp. wird ein neuer hoplocetiner Physeteride beschrieben. Der Fund stammt aus der Bolboforma fragori/subfragoris Zone des mittel-/obermiozänen Glimmertons von Groß Pampau in Schleswig-Holstein, Norddeutschland. Die Hoplocetinae sind vom unteren Miozän bis ins Pliozän nachgewiesen. Anhand vergleichender Untersuchungen an wenigen Schädelmerkmalen und der Zahnmorphologie gelingt eine Neudiagnose der Hoplocetinae Cabrera, 1926 und eine vorläufige Abgrenzung zwischen den als valid angesehenen Gattungen dieser Unterfamilie, Diaphorocetus, Idiorophus, Scaldicetus und Hoplocetus. Das Abkauungsmuster der Zähne von Hoplocetus ritzi n. sp. erinnert an das des heutigen Orcinus orca. Möglicherweise sind die hoplocetinen Pottwale habituell den Schwertwalen, die erdgeschichtlich erstmals im mittleren Pliozän auftreten, vergleichbar.

\section{Introduction}

Skeletal elements including teeth of a hoplocetine sperm whale were recovered by collectors of erratic boulders from the gravel pit of the Ohle company in early February 1997. This commercial gravel pit is located near the village Groß Pampau in Schleswig-Holstein, North Germany, about $35 \mathrm{~km}$ east of Hamburg (Fig. 1). During the frosty season caterpillar tractors unearthed the remains of what seemed to be a single large odontocete from the so called Glimmerton, a Miocene mica-rich clay which crops out under Pleistocene gravel. The private collectors recovered the obtainable bones, bone fragments and teeth in a quick "emergency" operation (Ritz \& Müller 1998). The fossil odontocete remains were found on a small Langenfeldian Glimmer-

\footnotetext{
*E-mail: oliver.hampe@museum.hu-berlin.de
} 
ton plateau (stratigraphic horizon, see Fig. 2) with bones and teeth scattered along an area of about $8.60 \mathrm{~m}$ in length (pers. comm. R. Ritz, Henstedt-Ulzburg). The remains comprise thirteen isolated teeth, eight vertebral centra, a single transverse process of a thoracic vertebra, two fragmentary ribs, one scapular fragment (acromion), one phalanx and several bits and pieces of undeterminable bone.

Since 1984 several marine mammal remains have been excavated from the mica-clay deposits at Groß Pampau. These include parts of at least three mysticetes, an articulated specimen belonging to the superfamily Delphinoidea (Höpfner 1991; Spaeth \& Lehmann 1992a, b; Moths \& Höpfner 1993; Behrmann 1995; Hampe 1999) as well as phocid fragments (Lierl 1995).

Initial observations led to the interpretation of the Groß Pampau remains as belonging to an early representative of the killer whale (Delphi-

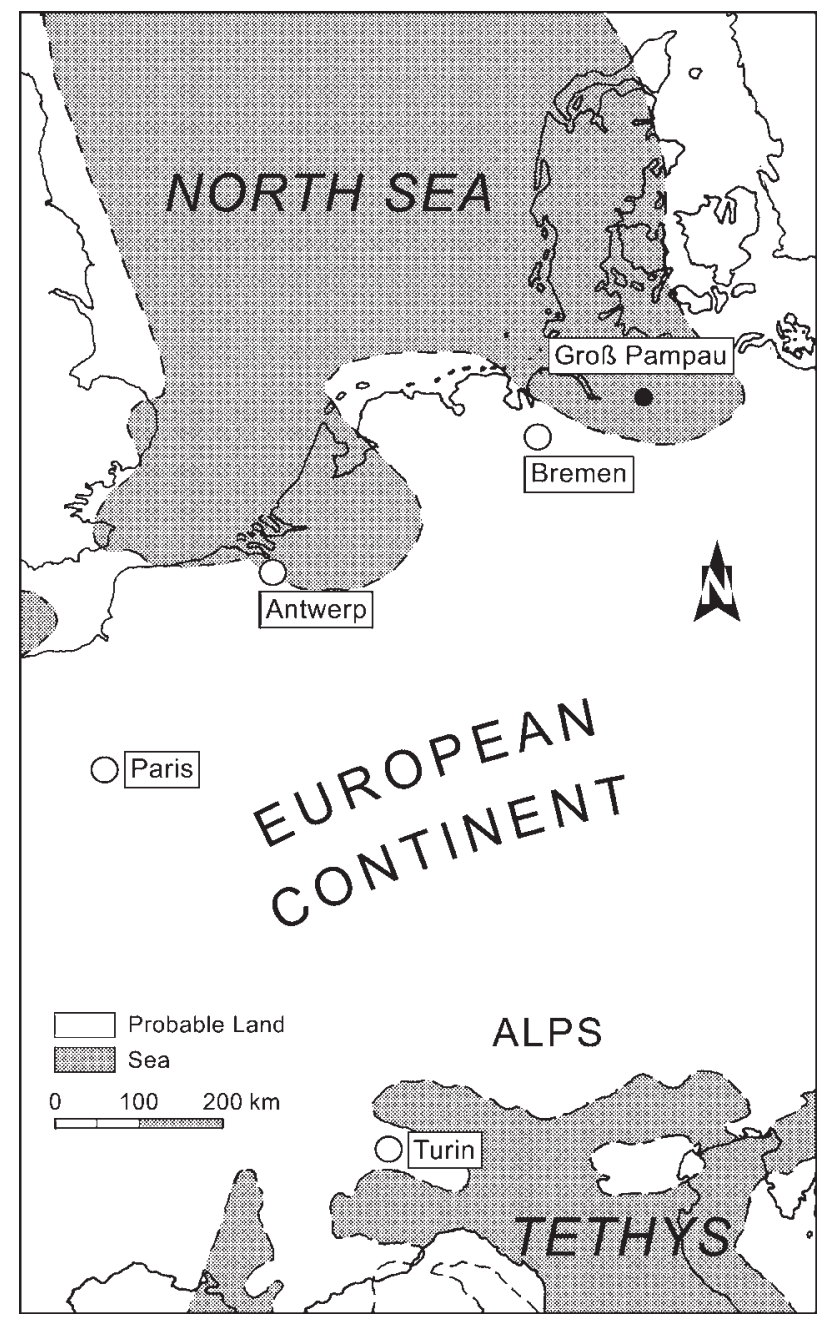

Fig. 1. Palaeogeographic map of part of West Europe set in approximately middle/late Miocene (after Ziegler 1990; Smith et al. 1994; Huuse 2002) showing the locality Groß Pampau in the North Sea Bay. nidae: Orcininae). Ritz \& Müller (1998: 19f) described the discovery as the remains of a sperm or killer whale. Hampe (1999) discussed the material after examination of the first available teeth as possibly representing a killer whale and pointed out some similarities with the description of the oldest known orcid, Orca semseyi from the lower Miocene of Hungary (Böckh 1899: jaw fragment with blunt, conical teeth). However, more recent work suggests that "Orca" semseyi belongs to the physeterids (Kazár 2003).

Only a few certain fossil physeterid remains have been mentioned so far from North Germany. Abel (1905a, p. 66) listed teeth of Scaldicetus grandis from Kreitz (Lüneburg), Langenfelde near Hamburg-Altona, and from Reinbek; Gripp (1964, p. 127) wrote about teeth of Scaldicetus near Wohltorf (exact whereabouts unknown).

\section{Short historical overview}

Physeterids have existed through a long interval in earth history. However, only three species of physeterids live at the present time: Physeter macrocephalus, and the pygmy and dwarf sperm whales, Kogia breviceps and K. sima. Anatomical data place physeterids at the base of the odontocetes, often as a sister group to the Ziphiidae (Heyning 1989; Barnes 1990; Muizon 1991). Modern molecular data also support a close relationship to the ziphiids (Gatesy 1998).

Ferecetotherium kelloggi from the lower Oligocene of Azerbaidjan (Mchedlidze 1984, pl. I-V, initially determined as an archaeocete) is still considered as the oldest known physeterid. The type consists of fragmentary skull elements, the left dentary including teeth, isolated teeth, incomplete cervical vertebrae, sternum and flipper elements.

Well known early Miocene physeterids include Diaphorocetus poucheti (Moreno 1892, pl. X, as Mesocetus) with a nearly complete cranium, and Idiorophus patagonicus (Lydekker 1893, pl. II, as Physodon), represented by a cranium and dentaries from Patagonia. The Argentinian species belong to a subfamily defined by Cabrera (1926, p. 408) as Hoplocetinae for physeterids having teeth in both the upper and lower jaw. However, some living Physeter macrocephalus have also teeth in the upper jaw, but the teeth are of uncertain number, mostly rudimentary and without function, and embedded in the gum (e.g., Boschma 1938). 


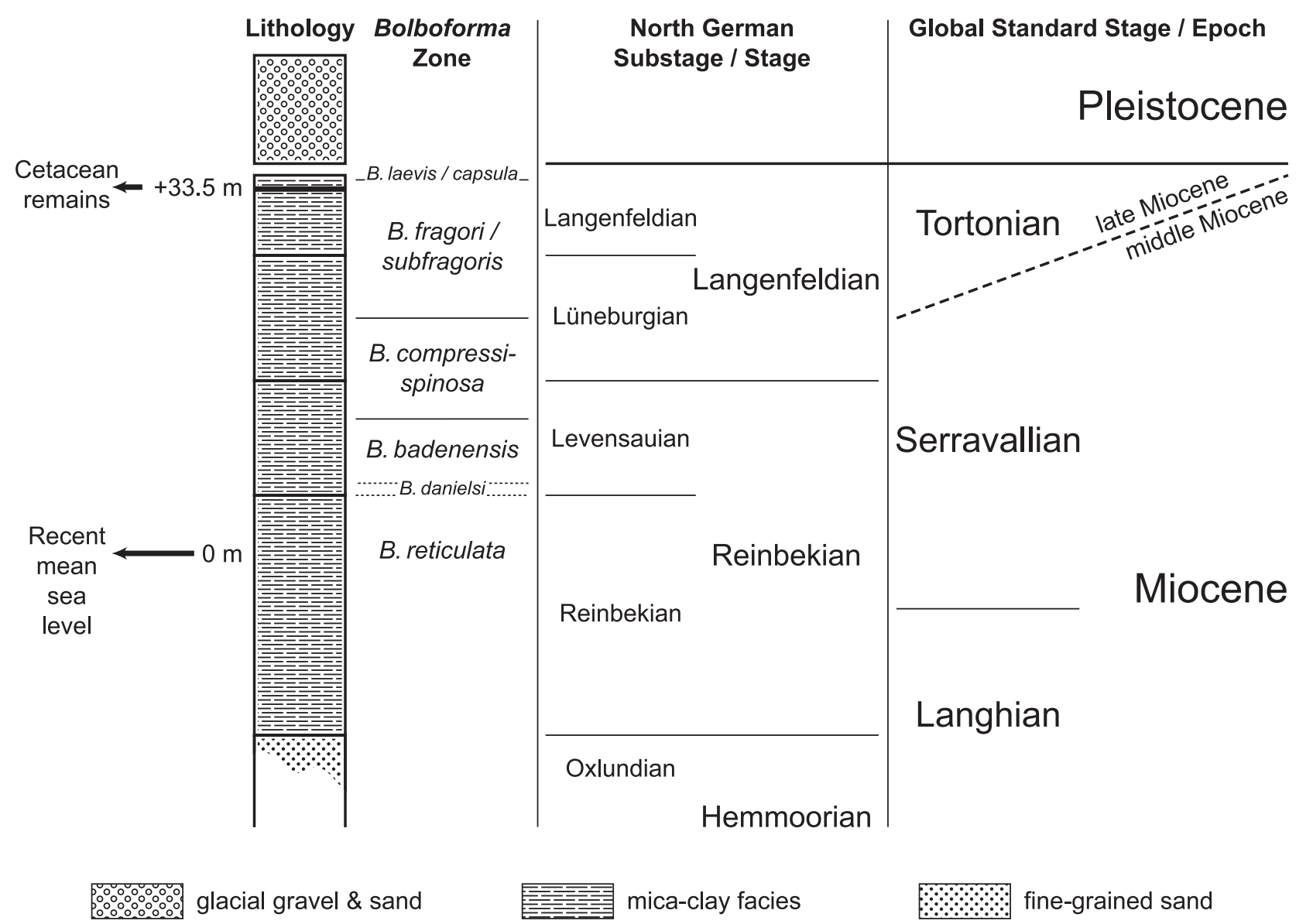

Fig. 2. Stratigraphy of the top Miocene marine sediments studied in the Ohle pit, Groß Pampau, Schleswig-Holstein, North Germany (compiled after Hinsch 1990, Höpfner 1991, Spiegler \& Gürs 1996, Gürs \& Spiegler 1999). The Bolboforma danielsi Zone was not recorded from the $36 \mathrm{~m}$ deep Groß Pampau I borehole (Spiegler \& Gürs 1996). The remains of Hoplocetus ritzi n. sp. were found in the B. fragori/subfragoris Zone. The mica-clay facies ends with the B. laevis/capsula Zone. This superimposed layer is of late Miocene age (Spiegler \& Gürs 1996). The Serravallian/Tortonian boundary is believed to be situated in the B. fragori/subfragoris Zone.

Another valid genus of the Hoplocetinae is Scaldicetus, many species of which are based on teeth. Recently, Hirota \& Barnes (1994, figs 5-17) described a nearly complete skeleton of Scaldicetus shigensis from the middle Miocene of central Japan. Scaldicetus caretti was described from the late Miocene of Belgium by $\mathrm{Du}$ Bus (1867). This species is documented by teeth, mainly cervical and thoracic vertebrae, and an epiphysis of the left humerus (Abel 1905a, figs 1, 2 ) and is therefore only poorly known. Scaldicetus mortselensis ( $\mathrm{Du}$ Bus 1872 as Eudelphis) from the late Miocene of Belgium consists of an incomplete skull (Abel 1905a, figs 5, 6). Another skull probably belonging to that genus from the earliest Pliocene Pisco Formation in Peru is still under preparation in the Muséum National d'Histoire Naturelle, Paris.

The systematics of the Hoplocetinae has frequently been discussed. Pilleri (1980), for example, noted, that this taxonomic group remains "still in many ways unclear". Muizon (1991) noted that the Hoplocetinae is defined by symplesiomorphies and may be non-monophyletic. Nevertheless, Fordyce \& Muizon (2001), following McKenna \& Bell (1997), classified the subfamilies Physeterinae and Hoplocetinae within the Physeteridae, but divided the pygmy sperm whales into their own family, Kogiidae. Kazár (2002) recognized the subfamilies Physeterinae, Aulophyseterinae and Kogiinae. She considered many genera, among them Scaldicetus and Hoplocetus, as having an unresolved systematic position and regarded the Hoplocetinae as incertae sedis, because the type species of the genus, $\mathrm{Ho}$ plocetus crassidens Gervais 1848, is based only on teeth.

Excellent fossils of the subfamily Physeterinae as defined by Kazár (2002) include Orycterocetus crocodilinus from the middle Miocene of midAtlantic coastal plain of North America (Gottfried et al. 1994) represented by several skulls, bullae and teeth, Physeterula dubusi from the late Miocene of Belgium with a nearly complete 
cranium and dentaries (Van Beneden 1877a, pl. 1; Abel 1905a, figs 11, 12), and Placoziphius duboisi from the middle Miocene of Belgium and Austria represented by crania, teeth and vertebrae (Kazár 2002, pl.1-4). Idiophyseter merriami (Kellogg 1925a, figs 1-4) consists only of an imperfect cranium.

The Aulophyseterinae are represented by only two species: Aulophyseter morricei Kellogg, 1927 from the middle Miocene Temblor Formation of California (brief description in Kellogg 1931, figs 106-108) with a superbly preserved skull, and Aulophyseter mediatlanticus (Cope 1895, as Paracetus) from the middle Miocene of Maryland and Florida (Case 1904, pl. 17: fig. 6a, b, as Hypocetus; Allen 1921, pl. 12, as Diaphorocetus). A comprehensive nomenclatural discussion of the latter species is given by Kazár (2002, p. 161).

\section{Local stratigraphic background}

A rich molluscan fauna and many fossil elasmobranch teeth derived from the Miocene mica-clay were found in the sieved gravels following the beginning of dredge prospection in the commercial gravel pit of the company August Ohle KG (Moths 1989, 1990, 1992, 1998). The mica-clay forms the base of the pit at Groß Pampau $17 \mathrm{~m}$ of the clay are exposed in the pit (Spiegler \& Gürs 1996, p. 135).

The fully marine mica-clay, called "Oberer Glimmerton" in regional stratigraphic terms (see Hinsch 1974), was deposited east of the large North German Tertiary troughs, stratigraphically between the upper Reinbekian and upper Langenfeldian stages (Hinsch 1990) and succeeded the paralic and continental cycle of the "Obere Braunkohlensande" (Hemmorian stage). Gripp (1964) estimated an entire thickness of over 200 $\mathrm{m}$ for the "Oberer Glimmerton" which is rich in organic matter and muscovite, and occasionally in pyrite, glauconite and carbonate. In reality, the thickness varies between $50 \mathrm{~m}$ and $1.000 \mathrm{~m}$ (Garding trough, North Sea Basin; Gürs, pers. comm.).

The layer containing the whale remains (Fig. 2) belongs to the upper Langenfeldian which was dated initially by the occurrence and range of specific molluscs (e.g. Hinsch 1972, 1986).

In 1988, the Geological Survey of SchleswigHolstein (Landesamt für Natur und Umwelt des Landes Schleswig-Holstein) sent down two drillings into the pit of Groß Pampau. The cores were studied biostratigraphically. Whereas mol- luscs, benthic foraminiferes and ostracods seem to be useful for palaeoecological interpretations and for regional biostratigraphy, planktonic organisms are better for large-scale biostratigraphic correlation. Spiegler \& Gürs (1996) presented a detailed vertical range of bolboforms, marine calcareous microfossils of yet uncertain origin with affinities to protophytic algae (Spezzaferri \& Rögl 2004), and showed them to be excellent markers. According to Spiegler \& Gürs (1996), the bolboforms enable a high resolution biostratigraphy and a correlation with the nannoplankton subdivisions. The level where the whale remains were discovered belongs to the Bolboforma fragori/subfragoris Zone (Fig. 2). This correlates according to latest studies with an age between 10.6 and $11.8 \mathrm{Ma}$ (Spiegler \& Gürs 1996, Table 5). The middle/upper Miocene boundary is dated astronomically at $11.6 \mathrm{Ma}$ (Lourens et al. 2004, ratified in 2003) and is therefore situated within the Bolboforma fragoril subfragoris Zone.

\section{Methods}

The fossil specimens described here were formerly the property of several amateur collectors. They were donated to the Museum für Naturkunde, Berlin, for research and description. All fossil remains were measured and digitally photographed after preparation and nearly all of the remains were drawn in ink.

Comparative studies were made in the collections of the Museum für Naturkunde (Berlin; used abbreviation in the text: MB), Aquazoo Löbbecke Museum (Düsseldorf), Naturmuseum Senckenberg (Frankfurt a. M.; SMF), Museum für Natur und Umwelt (Lübeck), Staatliches Museum für Naturkunde (Stuttgart), Institut Royal des Sciences Naturelles de Belgique (Brussels; IRSN), Muséum National d'Histoire Naturelle (Paris; MNHN), The Natural History Museum (London; BMNH), Museo Geologico Giovanni Capellini (Bologna; MGGCB), Museo di Storia Naturale e del Territorio dell'Università di Pisa (Calci), Museo di Geologia e Paleontologia (Florence), Istituto e Museo di Geologia dell'Università (Padova; IMGUP), Sezione di Paleontologia del Museo Regionale di Scienze Naturali (Turin; MRSNT), Magyar Állami Földtani Intézet $=$ Geological Institute of Hungary (Budapest), The Academy of Natural Sciences (Philadelphia, PA), Calvert Marine Museum (Solomons, MD), and of the Smithsonian National Museum of Natural History (Washington, D.C.; USNM).

Biometric analyses were not undertaken because the majority of hoplocetine teeth are extremely worn by functional abrasion.

\section{Systematic Palaeontology}

Order Cete Linné, 1758

Suborder Cetacea Brisson, 1762

Parvorder Odontoceti Flower, 1867

Superfamily Physeteroidea Gray, 1821 
Family Physeteridae Gray, 1821

Subfamily Hoplocetinae Cabrera, 1926

Type genus. Hoplocetus Gervais, 1848.

Diagnosis (emended after Cabrera 1926). Skull elements form a supracranial basin of low degree, supraoccipital shield obliquely truncated with lambdoid suture oriented dorsoanteriorly, regularly robust and massive tooth proportions, tooth crown with short enamel cap.

Referred genera. Hoplocetus Gervais, 1848; Scaldicetus Du Bus, 1867; Diaphorocetus Ameghino, 1894; Idiorophus Kellogg, 1925a.

Remarks. All Hoplocetinae possess both upper and lower jaw dentition. This feature also occurs in Aulophyseterinae and basal Physeterinae and therefore cannot be considered as diagnostic.

\section{Hoplocetus Gervais, 1848}

Type species. Hoplocetus crassidens Gervais, 1848.

Diagnosis (emended after Gervais 1848, restricted to the teeth). Presence of a constriction below the enamel crown.

Referred species. H. crassidens Gervais, $1848, H$. curvidens Gervais, 1848, H. borgerhoutensis Du Bus, 1872, H. ritzi n. sp.

Distribution. Miocene of the Molasse - Mediterranean/Tethys (Drôme/S France); middle/late
Miocene (Groß Pampau/N Germany); ?Pliocene (Hérenthals/Belgium) of the North Atlantic.

\section{Hoplocetus ritzi n. sp.}

Figs 3-6, 9-13

Holotype. MB.Ma. 50479.1-26, thirteen teeth, eight vertebrae and bone fragments from a single dislocated skeleton.

Etymology. Named after the finder of the specimen, Reiner Ritz.

Type locality. Groß Pampau, Schleswig-Holstein, North Germany.

Type horizon. Bolboforma fragori/subfragoris Zone, upper Langenfeldian, vicinity of Serravallian/Tortonian boundary.

Diagnosis (restricted to the teeth). Robust teeth with enamel cap showing a rugose proximal region and a smooth distal region. Differs from other species of Hoplocetus in the following way: $H$. crassidens has robust teeth with a completely rugose or striated enamel cap; $H$. curvidens has robust teeth with an enamel cap divided into three parts, each decreasing in diameter toward the tip, and with a proximal region bearing well-developed wavy striations on the anterobuccal side, while the middle and distal regions are smooth; $H$. borgerhoutensis has more slender teeth with an enamel cap completely covered with weak vertical striation.

Description. Teeth - All thirteen teeth are very robust and comparatively large (for measurements, see Table 1). The shape of the teeth

Table 1

Measurements of the teeth of Hoplocetus ritzi n. sp.

\begin{tabular}{|c|c|c|c|c|c|c|c|c|}
\hline $\begin{array}{l}\text { tooth } \\
\text { (inv. \#) }\end{array}$ & $\begin{array}{l}\text { probable } \\
\text { position }\end{array}$ & $\begin{array}{l}\text { total } \\
\text { length } \\
(\mathrm{mm})\end{array}$ & $\begin{array}{l}\text { maximum } \\
\text { diameter } \\
(\mathrm{mm})\end{array}$ & $\begin{array}{l}\text { max. antero- } \\
\text { posterior } \\
\text { diameter }(\mathrm{mm})\end{array}$ & $\begin{array}{l}\text { max. bucco-lin- } \\
\text { gual diameter } \\
(\mathrm{mm})\end{array}$ & $\begin{array}{l}\text { circumfer. } \\
\text { cementum- } \\
\text { dentine }(\mathrm{mm})\end{array}$ & $\begin{array}{l}\text { maximum } \\
\text { circumfer. } \\
(\mathrm{mm})\end{array}$ & $\begin{array}{l}\text { enamel } \\
\text { cap }\end{array}$ \\
\hline $\begin{array}{l}\text { MB.Ma } \\
50479.22\end{array}$ & ?terminal & 95 & 37 & 37 & 32 & 111 & 112 & yes \\
\hline $\begin{array}{l}\text { MB.Ma } \\
50479.20\end{array}$ & $\begin{array}{l}\text { symphysial/ } \\
\text { lateral }\end{array}$ & 112 & 42 & 41 & 40 & 129 & 134 & no \\
\hline $\begin{array}{l}\text { MB.Ma } \\
50479.2\end{array}$ & $\begin{array}{l}\text { symphysial/ } \\
\text { lateral }\end{array}$ & 117 & 39 & 40 & 39 & 125 & 130 & no \\
\hline $\begin{array}{l}\text { MB.Ma } \\
50479.1\end{array}$ & $\begin{array}{l}\text { symphysial/ } \\
\text { lateral }\end{array}$ & 118 & 48 & 47 & 45 & 144 & 148 & no \\
\hline $\begin{array}{l}\text { MB.Ma } \\
50479.6\end{array}$ & $\begin{array}{l}\text { symphysial, } \\
\text { ?dentary }\end{array}$ & 123 & 40 & 39 & 37 & 116 & 124 & yes \\
\hline $\begin{array}{l}\text { MB.Ma } \\
50479.5\end{array}$ & $\begin{array}{l}\text { lateral, } \\
\text { ?maxilla }\end{array}$ & 114 & 44 & 43 & 37 & 122 & 132 & no \\
\hline $\begin{array}{l}\text { MB.Ma } \\
50479.3\end{array}$ & $\begin{array}{l}\text { symphysial/ } \\
\text { lateral }\end{array}$ & 131 & 48 & 46 & 46 & 144 & 154 & no \\
\hline $\begin{array}{l}\text { MB.Ma } \\
50479.4\end{array}$ & $\begin{array}{l}\text { symphysial/ } \\
\text { lateral }\end{array}$ & 135 & 47 & 46 & 42 & 136 & 136 & no \\
\hline $\begin{array}{l}\text { MB.Ma } \\
50479.21\end{array}$ & $\begin{array}{l}\text { symphysial/ } \\
\text { lateral }\end{array}$ & 136 & 46 & 44 & 41 & 133 & 141 & no \\
\hline $\begin{array}{l}\text { MB.Ma } \\
50479.23\end{array}$ & $\begin{array}{l}\text { symphysial/ } \\
\text { lateral }\end{array}$ & 150 & 46 & 45 & 42 & 137 & 141 & yes \\
\hline $\begin{array}{l}\text { MB.Ma } \\
50479.18\end{array}$ & $\begin{array}{l}\text { posterior, } \\
\text { dentary }\end{array}$ & (111) & 37 & 27 & 37 & 99 & 109 & yes \\
\hline $\begin{array}{l}\text { MB.Ma } \\
50479.19\end{array}$ & $\begin{array}{l}\text { posterior, } \\
\text { dentary }\end{array}$ & $(92)$ & 36 & 31 & 36 & 114 & 115 & no \\
\hline $\begin{array}{l}\text { MB.Ma } \\
50479.24\end{array}$ & $\begin{array}{l}\text { posterior, } \\
\text { maxilla }\end{array}$ & 96 & 51 & 44 & 46 & - & 153 & no \\
\hline
\end{tabular}




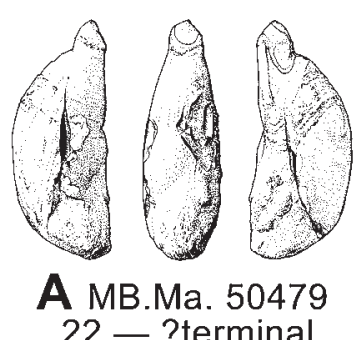

.22 - ?terminal
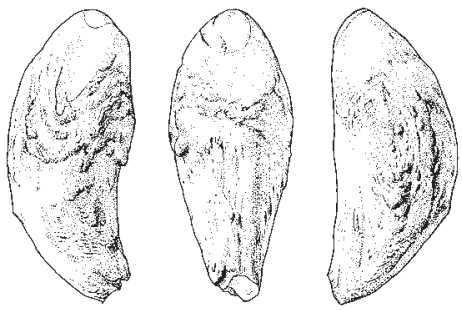

D .1- symphysial / lateral
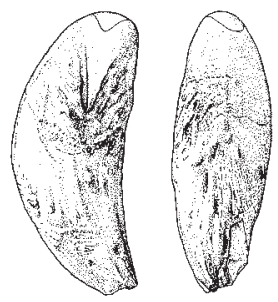

B

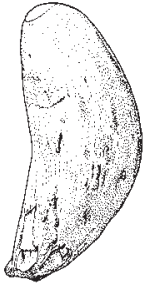

.20 - symphysial / lateral

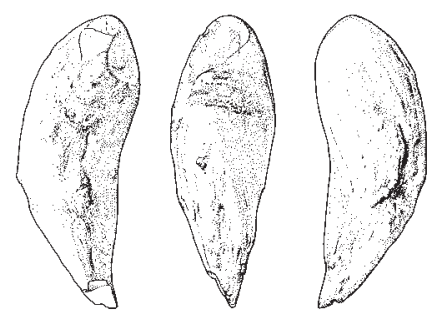

C .2- symphysial / lateral

\section{F .5- lateral, ?maxilla}
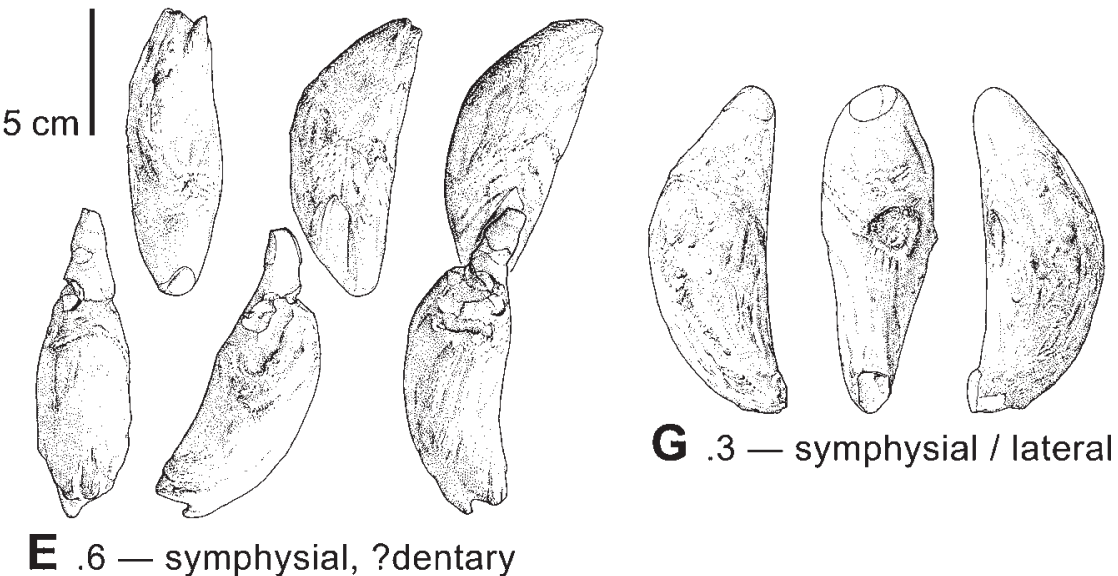

G .3-symphysial / lateral

\section{E .6- symphysial, ?dentary}

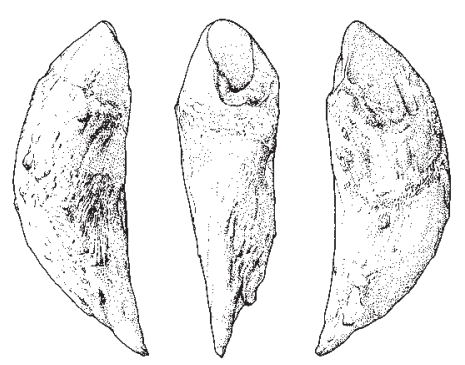

H .4- symphysial / lateral

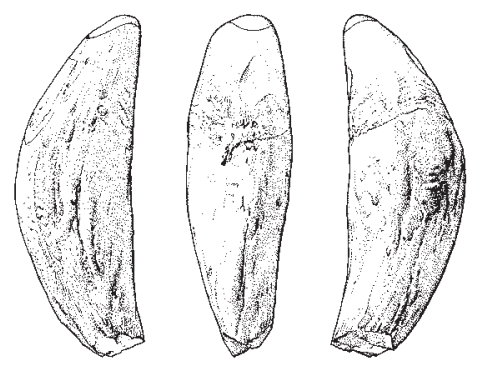

I .21- symphysial / lateral

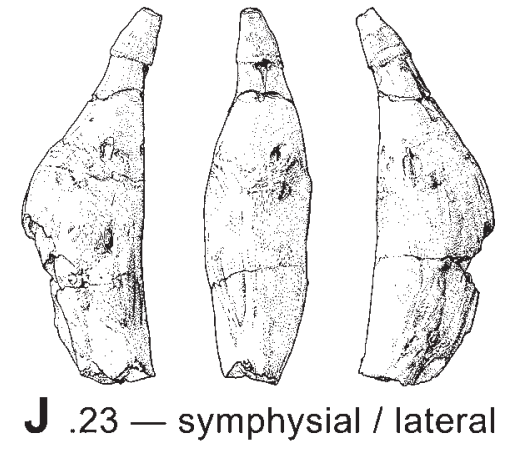

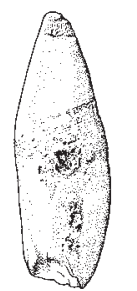
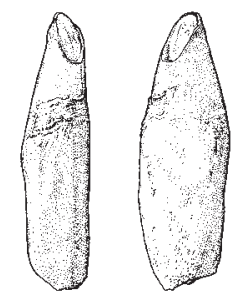

K. 18

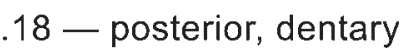

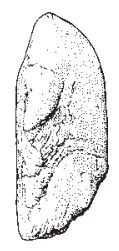
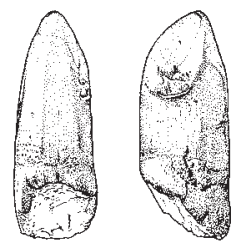

L. 19 - posterior, dentary
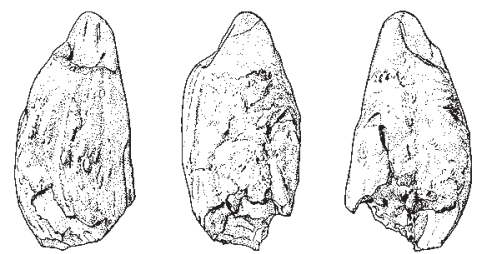

M .24-posterior, maxilla

Fig. 3. The entire set of preserved teeth of Hoplocetus ritzi n. sp. shown in different views: right-handed convex aspect (left), postero-lingual aspect (middle), left-handed convex aspect (right). The correct orientation of teeth MB.Ma. 50479.18, 19 and $24(\mathbf{K}, \mathbf{L}, \mathbf{M})$ is not certain. The probable position within the jaws is indicated. The antagonists MB.Ma. 50479.6 and 5 (E, F) are shown in postero-lingual aspect (left), exhibiting their wear facets (middle), and in functional contact (right).

is similar to that of thick and stumpy bananas (Figs 3-5), of more or less circular cross-section. All teeth bear strongly developed contact facets. The crown is heavily abraded in some teeth, caused by interaction with the opposing tooth of the opposite jaw (Fig. 5). In one pair of upper and lower jaw teeth the contact surfaces of the crowns fit exactly together (see below). The expressed dentine of the crown is covered with a small enamel cap as seen in less strongly 


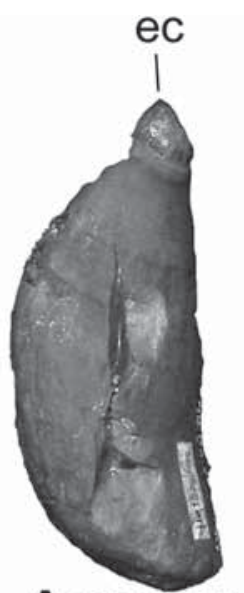

A MB.Ma. 50479 .22 ?terminal

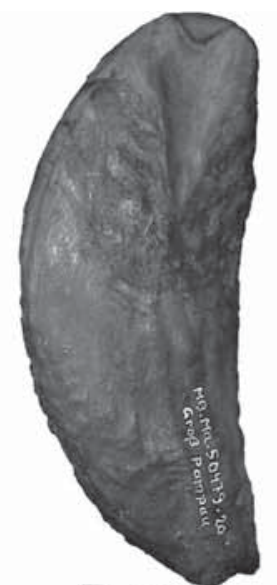

B . 20

lateral /

symphysial

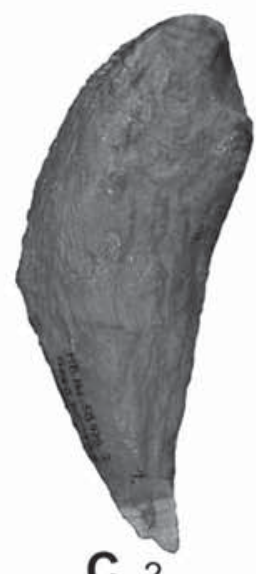

C .2

lateral /

symphysial

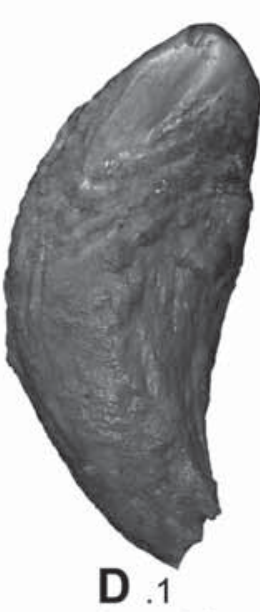

lateral /

symphysial

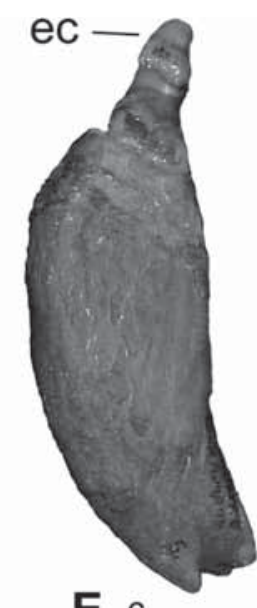

E .6

symphysial, ?dentary

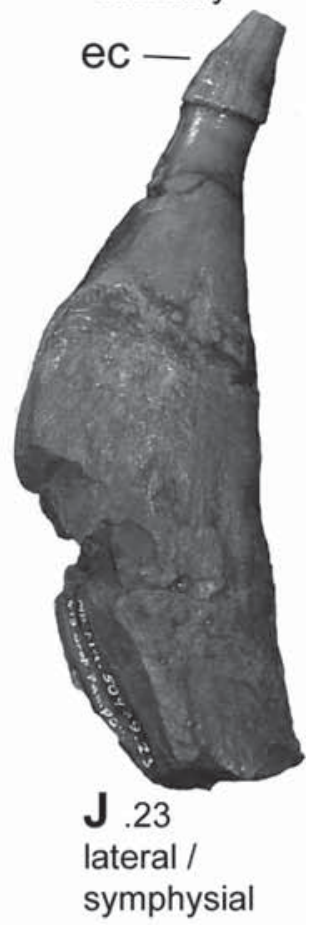

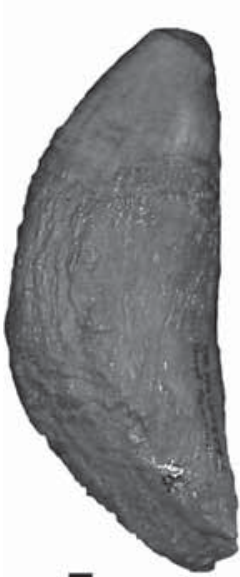

F . 5

lateral,

?maxilla

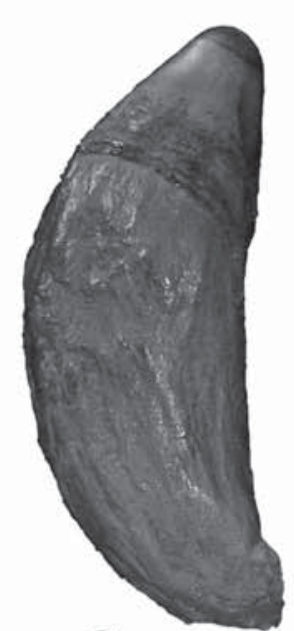

G .3

lateral / symphysial

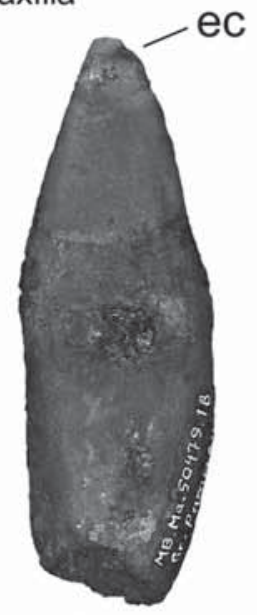

K.18

posterior, dentary

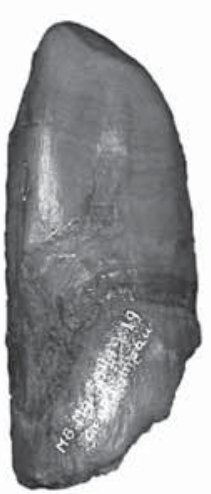

L. 19 posterior, dentary

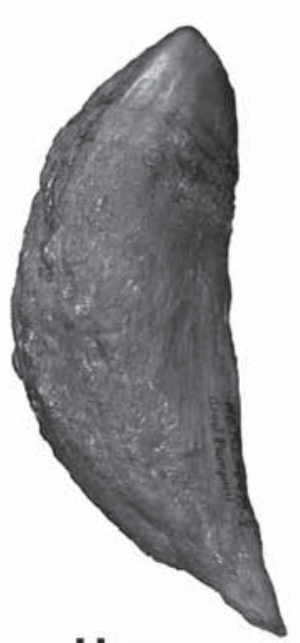

H .4

lateral /

symphysial

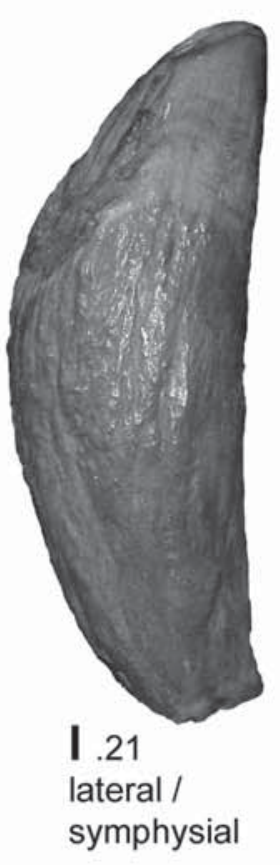

symphysial

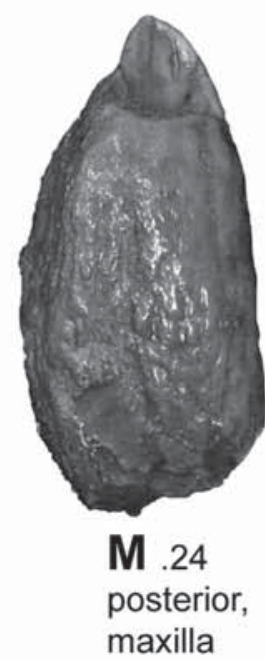

Fig. 4. Hoplocetus ritzi n. sp.: Teeth with right-handed convex aspect. Specimens $\mathbf{A}, \mathbf{E}, \mathbf{J}$, and $\mathbf{K}$ retain parts of the enamel cap. The lingual or buccal view is displayed for the probable posterior dentary teeth $(\mathbf{K}, \mathbf{L})$. ec - enamel cap. 


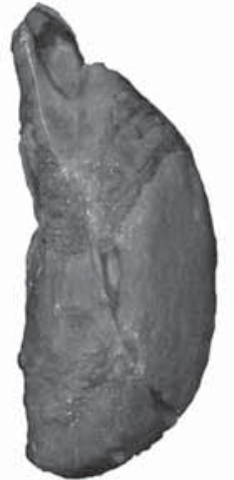

A MB.Ma. 50479 .22 ?terminal

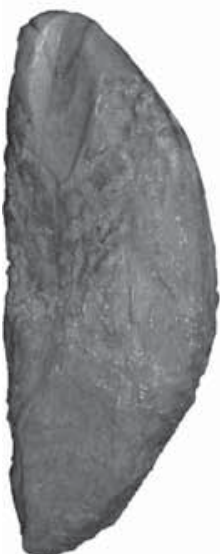

F . .5

lateral,

?maxilla

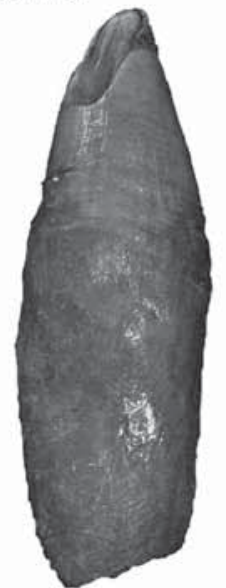

K.18

posterior, dentary

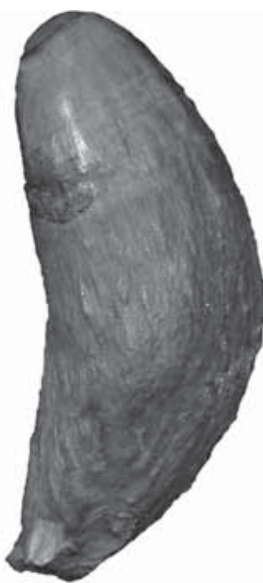

B .20

lateral / symphysial

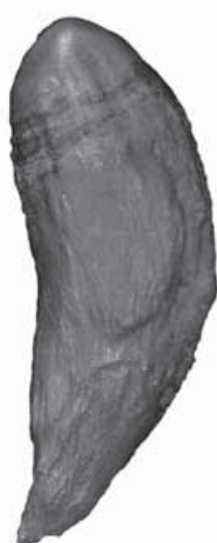

C. 2

lateral /

symphysial

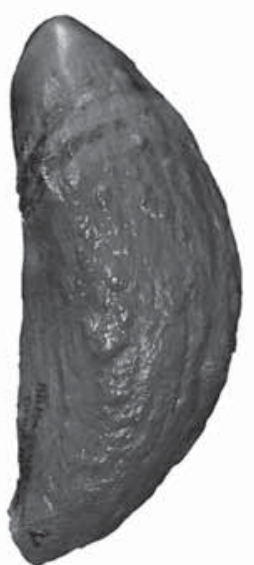

D. 1

lateral /

symphysial

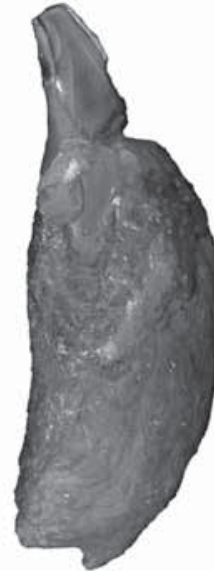

E .6 symphysial, ?dentary

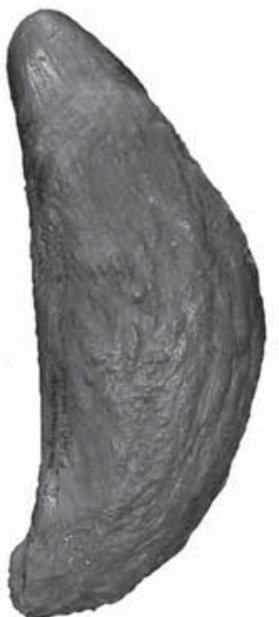

G .3 lateral / symphysial

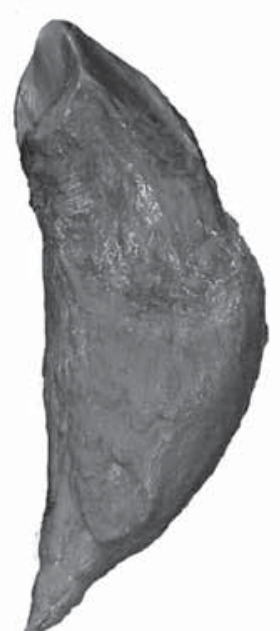

H .4 lateral/ symphysial

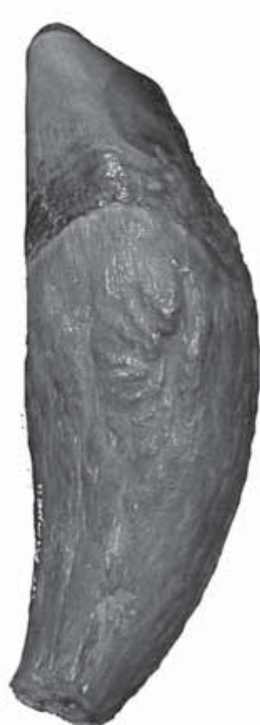

I 21 lateral / symphysial

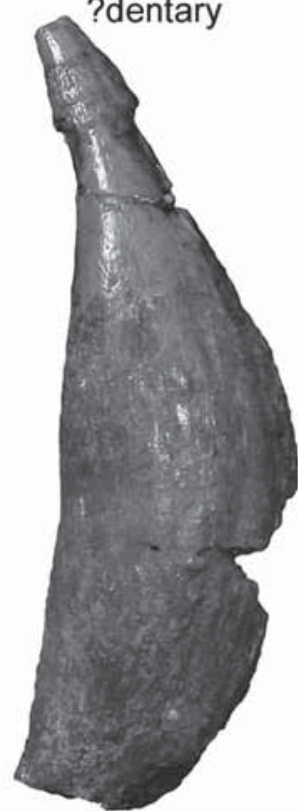

J.23

lateral / symphysial
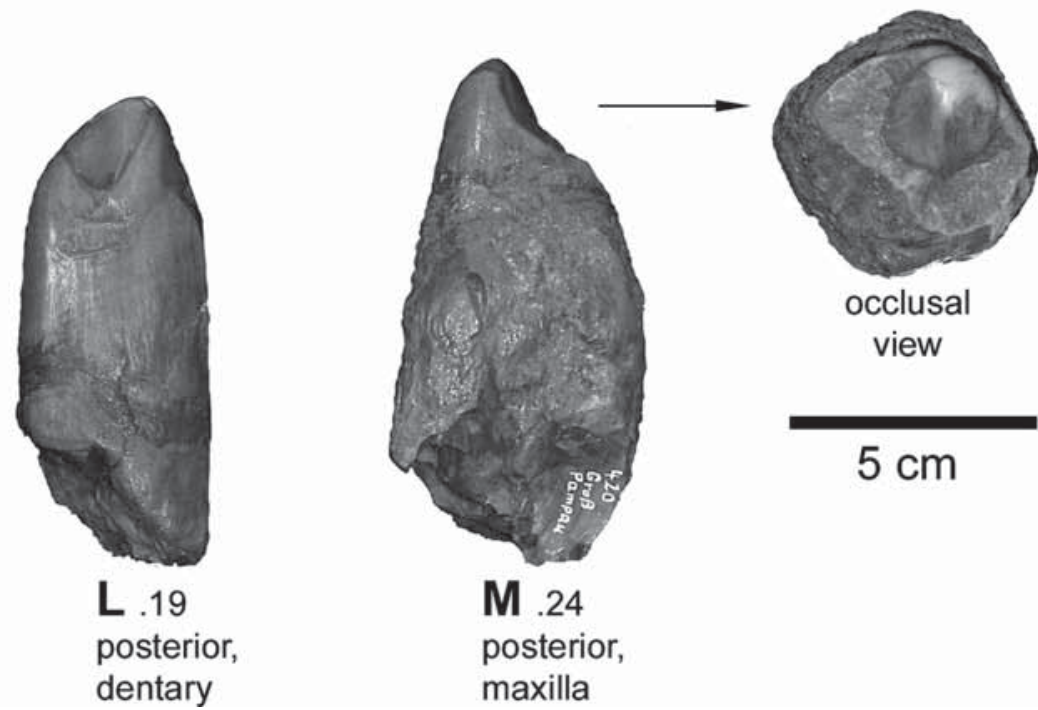

M .24

posterior, maxilla

Fig. 5. Hoplocetus ritzi n. sp.: Teeth with left-handed convex aspect. The probable posterior dentary teeth $(\mathbf{K}, \mathbf{L}, \mathbf{M})$ are shown with their opposite side (lingual or buccal; see Fig. 4). Tooth $\mathbf{M}$ is also displayed in occlusal view. 


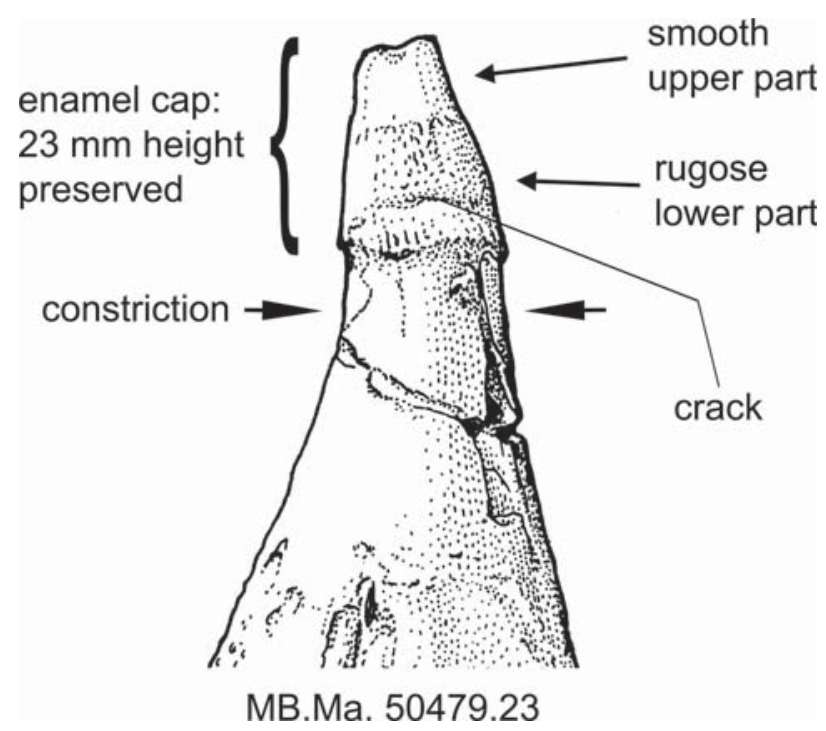

Fig. 6. Hoplocetus ritzi n. sp.: MB.Ma. 50479.23, characters of the tooth crown.

abraded teeth. Generally, the cap can be divided into a rugose proximal region followed by a smooth distal region (Fig. 6). The apex of the cap is not preserved in the Groß Pampau teeth. The dentine below the enamel cap is constricted (Fig. 6).

The massive root is covered with cementum and bears an irregular dark band at the transition to the crown. This dark band is interpreted as corresponding to the gingival or alveolar margin ("cementum collar", e.g. Varola et al. 1988). Nearly all teeth show a closed pulp cavity. The root is mainly of a dirty dark brown colour, the dentine of the crown of somewhat lighter brown, and the enamel cap is dark grey. All teeth are partly masked by pyrite encrustations.

In order to understand the terminology of orientation it is important to point out that the curvature of physeterid teeth is generally postero-lingually directed (Fig. 7) as in the extant Physeter macrocephalus and in well preserved fossil jaws of ?Idiorophus bolzanensis from the lower Miocene (late Aquitanian) of North Italy (see below) or the middle Miocene Scaldicetus shigensis (Hirota \& Barnes 1994, figs 9-11) from Japan.

Since it is extremely difficult to identify isolated teeth as belonging to the upper or lower dentition, a tentative allocation of the preserved teeth for Hoplocetus ritzi n. sp. was not attempted. Nevertheless, it is generally possible to distinguish between terminal teeth, symphysial and/or lateral teeth and posterior teeth (Fig. 8).

MB.Ma. 50479.22 (Figs 3A, 4A, 5A) probably represents a tooth placed far anteriorly. It is a relatively small tooth (as in Physeter, Boschma
1938, fig. 10). The tooth is only slightly curved. Some parts of the root are chipped off, probably a taphonomical feature. The buccal/anterior aspect of the tooth (see Fig. 7 for general orientation) shows a deep, wedge-shaped contact surface. Only half of the proximal enamel cap is preserved.

The following teeth display symphysials (dentary) or laterals (maxilla). MB.Ma. 50479.20 (Figs 3B, 4B, 5B) is the shortest lateral tooth, $11.2 \mathrm{~cm}$ in height. The abrasive traces on the buccal/anterior side are wedge-shaped and end downwards in a point. An enamel cap is not preserved. The root is directed slightly postero-lingually and originally bore three little processes.

MB.Ma. 50479.2 (Figs 3C, 4C, 5C) has the smallest maximum diameter of all the symphysial/lateral teeth. The preserved crown is very short, the abrasional contact is small and even, not developed into a deep fossa. The cementum below the abrasion has a rough surface, and might have been affected by contact with the opposite tooth. A lingual/posterior, thumbnail-sized piece of the crown has been broken away probably by the impact of the opposite tooth. No enamel cap is preserved on this tooth. The root has one proximal process; a rudimentary process is buccally/anteriorly oriented.

MB.Ma. 50479.1 (Figs 3D, 4D, 5D) has the largest antero-posterior diameter $(4.7 \mathrm{~cm})$ of all teeth from the Groß Pampau site. The crown is flattened on the buccal/anterior side by distinct functional abrasion. Below the crown, the ce-

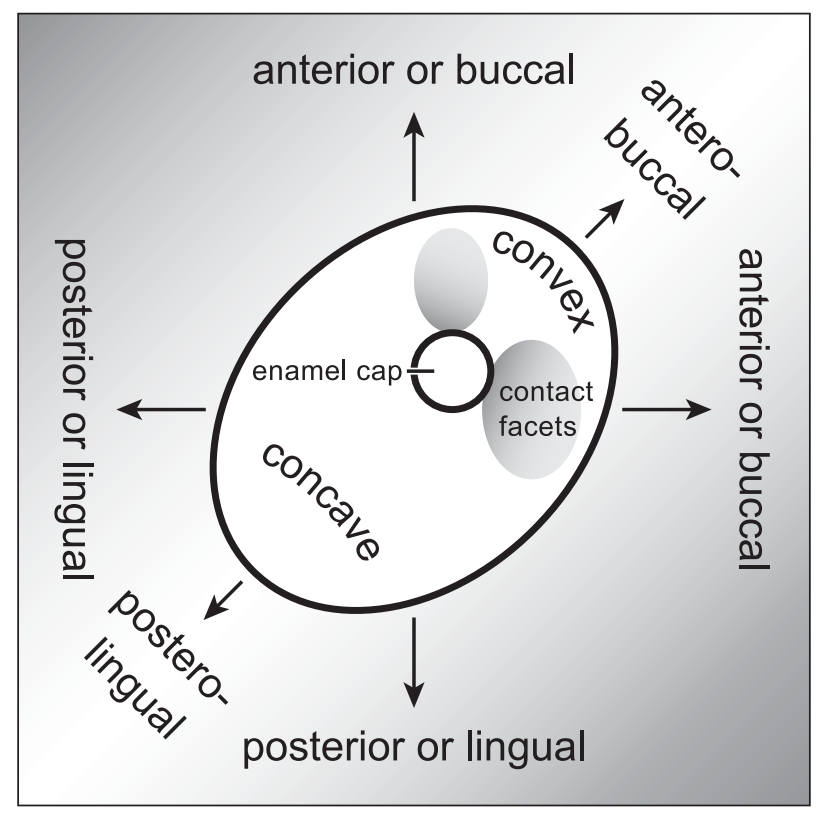

Fig. 7. Orientation of hoplocetine teeth: schematic tooth in coronal (apical) aspect. The abrasive contact surfaces usually occur on buccal or anterior aspects. 


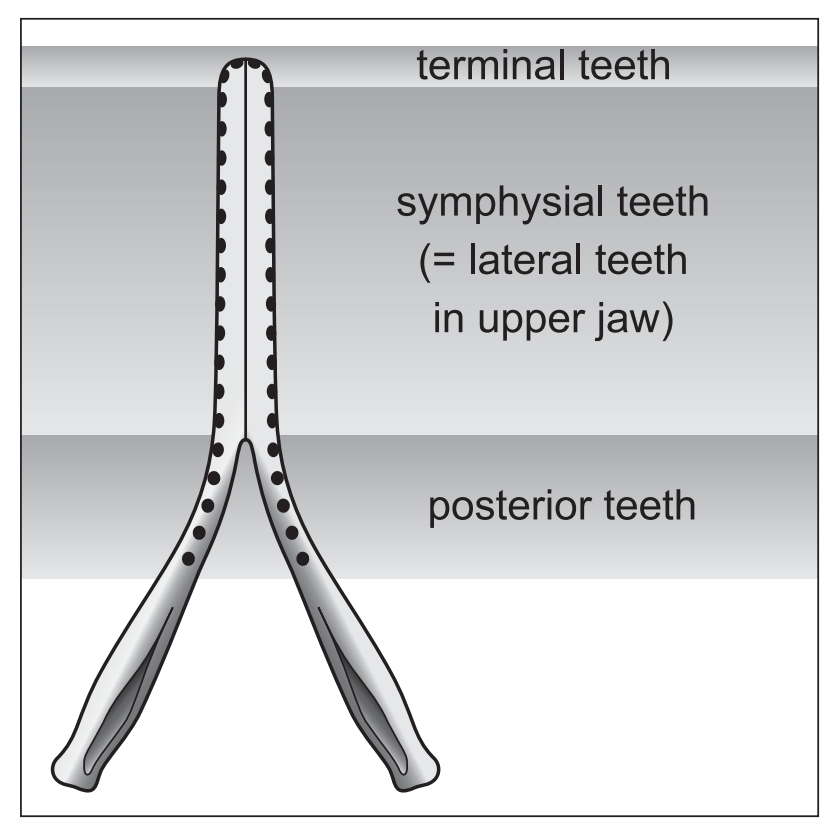

Fig. 8. Terminology for the position of the teeth of a physeterid in a schematic dentary in dorsal view.

mentum forms a U-shaped indentation. The cementum exhibits a strongly nodular character, especially in postero-buccal and anterio-lingual aspects. No enamel cap is preserved on this tooth. The root has three short processes, one is prominent (broken), the other two are minute. This specimen is also interpreted as a symphysial/lateral tooth.

The crown of MB.Ma. 50479.6 (Figs 3E, 4E, $5 \mathrm{E})$ gradually tapers and bears an enamel cap of about $1.5 \mathrm{~cm}$ height of which the apex is broken away. The cap is $1.5 \mathrm{~mm}$ thick and has, as mentioned above, an apparently rugose proximal belt separating it from the distal part, which is characterised by a smooth surface. The buccal/anterior half of the enamel cap is completely abraded. Most parts of the dentine region of the crown are chipped away, probably by taphonomic processes. In any case, a distinct constriction is visible below the enamel cap. The root has three obtuse processes (two positioned postero-lingually and one antero-buccally).

MB.Ma. 50479.5 (Figs 3F, 4F, 5F) is less curved. This tooth evidently forms the counterpart to tooth MB.Ma. 50479.6 (Figs 3E, 4E, 5E). The contact surfaces on both crowns fit exactly together (Figs 3E, F). The crown of MB.Ma. 50479.5 exhibits a $12 \mathrm{~mm}$ broad, vertical, strip-shaped pattern of tooth wear which is, as usual, located buccally or anteriorly. This tooth also has no enamel cap preserved. The root has three short, obtuse processes. This specimen is most probably a lateral tooth, possibly from the maxilla.
MB.Ma. 50479.3 (Figs 3G, 4G, 5G) has the greatest maximum circumference, with $15.4 \mathrm{~cm}$, of all preserved teeth. This symphysial/lateral tooth has a relatively extensive abrasive surface, located on the antero-buccal aspect. A 5 to $7 \mathrm{~mm}$ broad vertical groove on this broad wear resulted from contact with the enamel cap of the counterpart tooth. The other side of the crown reveals, in addition, a smooth, oval-shaped abrasive trace. MB.Ma. 50479.3 has no enamel cap. The root shows a strong, broken postero-lingually directed process. There is a rounded impression on the concave aspect in the upper cementum-covered region. This impression can not be explained by regular development or functional contact and is more likely interpreted as possible pyrite destruction.

The crown of MB.Ma. 50479.4 (Figs 3H, 4H, $5 \mathrm{H}$ ) is strongly worn on its buccal/anterior aspect. Here the cementum is deeply recessed. On the counterside, the cementum has an extremely rough and nodular character. Part of the crown is broken away on the postero-lingual side, and has sharp vertical edges. The root has a single pointed process. A rudimentary projection is located about $20 \mathrm{~mm}$ further upwards on the antero-lingual or postero-buccal side.

MB.Ma. 50479.21 (Figs 3I, 4I, 5I) can be described as a twin of MB.Ma. 50479.3 (Figs 3G, $4 \mathrm{G}, 5 \mathrm{G})$. The abrasive tooth wear of the crown is located on the antero-buccal aspect and is also relatively extensive. Some distinct, thin, vertical scratches are developed on this surface. The postero-lingual aspect shows also a smooth abrasive oval as in MB.Ma.50479.3. An enamel cap is missing, and the root is not completely preserved, the proximal end is broken.

MB.Ma. 50479.23 (Figs 3J, 4J, 5J) is $15 \mathrm{~cm}$ in height and the largest of the preserved teeth of Hoplocetus ritzi n. sp. The tooth is less curved and has only minor abrasions at the crown, possibly because of a slight inclination of the cusp. The apex of the enamel cap is broken and only $2.3 \mathrm{~mm}$ of the cap are preserved. The enamel has a characteristic rugose proximal region followed by a smooth distal region. The root is damaged on the lower part of the antero-buccal side - the termination is broken. This specimen forms the last of the presumed symphysial/lateral teeth.

MB.Ma. 50479.18 (Figs 3K, 4K, 5K) has a different morphology to the teeth discussed so far. This tooth was very probably situated in the posterior part of the tooth row of the dentary by comparison to the as yet undescribed Peruvian 


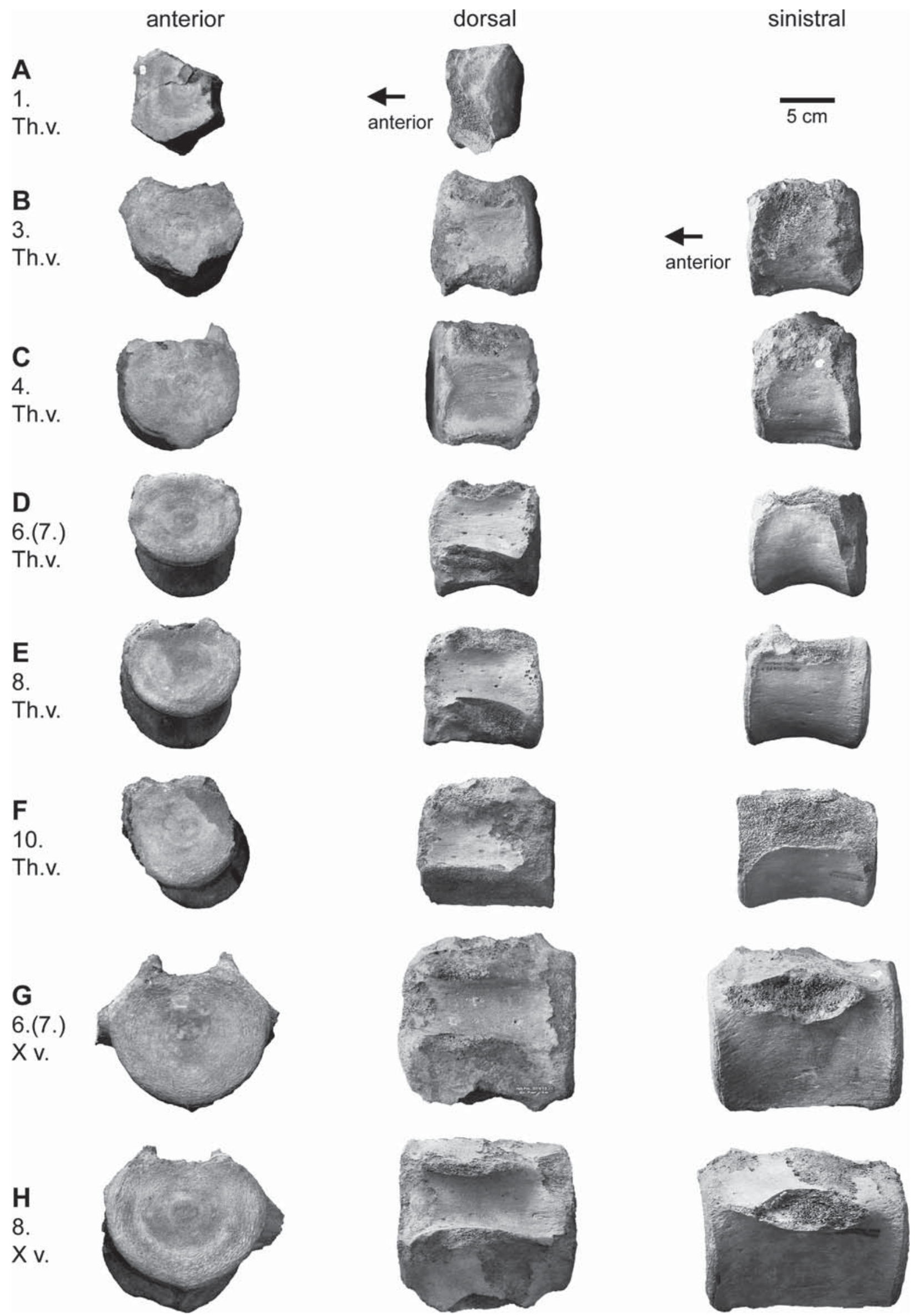

Fig. 9. Hoplocetus ritzi n. sp.: vertebrae, MB.Ma. 50479.14 (A), $16(\mathbf{B}), 15(\mathbf{C}), 7$ (D), 8 (E), 9 (F), $17(\mathbf{G}), 10(\mathbf{H})$ in three aspects. Th.v. - thoracic vertebrae; X v. - containing lumbar and sacral vertebrae, in the meaning of De Smet (1977). 
hoplocetine specimen (Muizon \& Lambert, in prep.; see also Boschma 1938, figs 14, 15 for Physeter). MB.Ma. 50479.18 has the lowest circumference of any of the preserved teeth at the dentine-cementum transition. The tooth is flattened laterally (probably lingual and buccal aspects) and presents throughout an oval to rectangular cross-section. MB.Ma. 50479.18 is completely straight. The upper half of the crown has a diagonal contact abrasion on the probable antero-buccal aspect. The lower rugose belt of the apical enamel cap remains on the opposite side. Corrosions on the cementum seem to have a taphonomic origin (see above: pyrite). The end of the root displays a broad, open pulp canal filled with sediment.

MB.Ma. 50479.19 (Figs 3L, 4L, 5L) represents a posterior tooth, which also does not exhibit any clear curvature. Most of the root is broken away and heavily pyritised. The tooth is laterally compressed, as in MB.Ma. 50479.18, and shows tooth wear consisting of two horizontally oriented abrupt carvings on the probable buccal aspect. The shape of the blunt (abraded) crown resembles a blade. It is remarkable that the cementum (dark band) has an indentation opposite to the tooth wear (postero-lingually). The enamel cap is also not preserved here.

MB.Ma. 50479.24 (Figs 3M, 4M, 5M) is a particularly massive specimen with an extremely thick root. It seems, that this specimen could be a posterior tooth of the maxilla because this element generally offers more space for such a tooth type. The shortest and thickest dentary teeth of the living Physeter are found in posterior positions (see Boschma 1938, fig. 7). The cross-section of the tooth is square in shape. The top of the crown is strongly abraded. Two approximately right angled fragments were chipped away (see Figs 4M, 5M). The enamel cap is not preserved. The orientation of the specimen cannot be determined with certainty because of the symmetric shape of this tooth.

Trunk - The vertebral column is represented by eight vertebral centra (Fig. 9). Cervicals are not preserved. Six centra belong to the thoracic region, and two are members of the lumbar region, the section containing the largest vertebrae. One isolated transverse process was also found (Fig. 10).

The vertebra determined as the first thoracic vertebra (MB.Ma. 50479.14, Fig. 9A) is poorly preserved with an incomplete centrum. Large areas of the ventral and sinistral aspects and

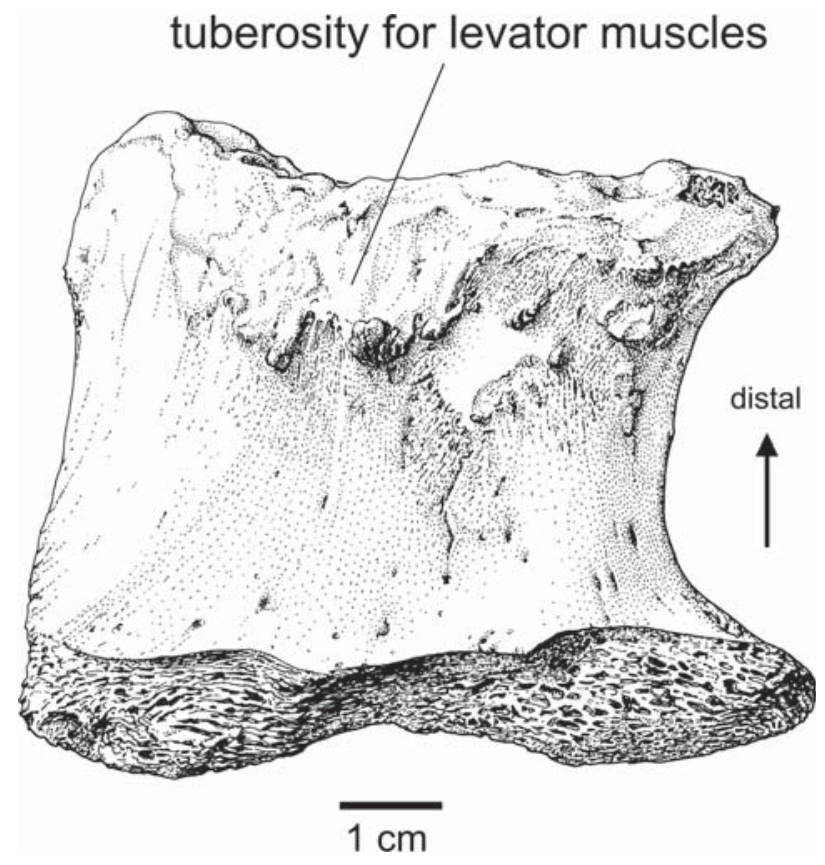

Fig. 10. Hoplocetus ritzi n. sp.: isolated transverse process of the thoracic region, MB.Ma. 50479.11, in dorsal view.

parts of the dorsal surface are broken away. Exposed interior areas show normal spongiosa, free from signs of disease.

There is a difference in length of more than $2 \mathrm{~cm}$ with the next preserved thoracic vertebra which is supposedly the third thoracic vertebra (MB.Ma. 50479.16, Fig. 9B). The centrum is generally rounded with a slightly heart-shaped outline in anterior or posterior view. The dorsal surface is plane and reveals two small foramina in the middle of the centrum. The right foramen is situated more posterior than the left one. The ventral side exhibits a longitudinal midline, but a keel is not developed. A large, slightly oval impression (foramen) appears right of the midline. Large ventral foramina indicate the entrances of the basivertebral veins which emerge from the dorsal side of the centra, trend ventro-laterally and connect with the ventral longitudinal spinal veins. The small openings on the surface resulted from channels entering into the bone. Katapophyses, which correspond with the facet of the costal capitulum (see Slijper 1936), could not be identified owing to the poor state of preservation.

The fourth thoracic vertebra (MB.Ma. 50479.15, Fig. 9C) is generally of the same shape as the third thoracic vertebra. The dorsal surface bears two oval shaped foramina which lie opposite each other. The ventral side exhibits a slightly rugose surface. The posterior height of fourth thoracic vertebra is noticeably greater than the anterior height (see Table 2). The pos- 
Tab. 2

Measurements of the vertebral centra of Hoplocetus ritzi n. sp.

\begin{tabular}{|c|c|c|c|c|c|c|c|}
\hline inv. \# & $\begin{array}{l}\text { vertebral } \\
\text { centrum }\end{array}$ & $\begin{array}{l}\text { length }(\mathrm{mm}) \text {, } \\
\text { dorsal }\end{array}$ & $\begin{array}{l}\text { length }(\mathrm{mm}) \text {, } \\
\text { ventral }\end{array}$ & $\begin{array}{l}\text { width }(\mathrm{mm}) \text {, } \\
\text { anterior }\end{array}$ & $\begin{array}{l}\text { width }(\mathrm{mm}) \text {, } \\
\text { posterior }\end{array}$ & $\begin{array}{l}\text { height }(\mathrm{mm}) \text {, } \\
\text { anterior }\end{array}$ & $\begin{array}{l}\text { height }(\mathrm{mm}) \text {, } \\
\text { posterior }\end{array}$ \\
\hline $\begin{array}{l}\text { MB.Ma } \\
50479.14\end{array}$ & 1. Th.v. & $66^{*}$ & &.$/$ &. &.$/$ &.$/$ \\
\hline $\begin{array}{l}\text { MB.Ma } \\
50479.16\end{array}$ & 3. Th.v. & 88 & 88 & 103 & (104) & (84) & 88 \\
\hline $\begin{array}{l}\text { MB.Ma } \\
50479.15\end{array}$ & 4. Th.v. & 84 & 85 & 105 & 105 & 90 & 99 \\
\hline $\begin{array}{l}\text { MB.Ma } \\
50479.7\end{array}$ & (6.)7. Th.v. & 102 & 99 & 105 &.$/$. & 92 & 95 \\
\hline $\begin{array}{l}\text { MB.Ma } \\
50479.8\end{array}$ & 8. Th.v. & 109 & 107 & 105 & 111 & 94 & 99 \\
\hline $\begin{array}{l}\text { MB.Ma } \\
50479.9\end{array}$ & 10. Th.v. & 118 & 115 & 105 &. & 97 &. \\
\hline $\begin{array}{l}\text { MB.Ma } \\
50479.17\end{array}$ & (6.)7. X v. & 147 & 145 & 131 & 136 & 109 & 111 \\
\hline $\begin{array}{l}\text { MB.Ma } \\
50479.10\end{array}$ & 8. X v. & 154 & 149 & 135 & 136 & 109 & 112 \\
\hline
\end{tabular}

terior epiphysis projects ventrally, and is more distinct than in other preserved vertebrae.

What is probably the sixth/seventh thoracic vertebra (MB.Ma. 50479.7, Fig. 9D) has almost an hourglass form in ventral view as in the third and fourth thoracic vertebra. Several foramina of the blood vascular system are situated on the dorsal surface. The anterior epiphysis is completely circular.

The morphology of the following centrum, the eighth thoracic vertebra (MB.Ma. 50479.8, Fig. 9E) does not deviate from its predecessor, although the hourglass shape is less developed. Small, oval-shaped impressions on the ventro-lateral surfaces are present.

On the tenth thoracic vertebra (MB.Ma. 50479.9, Fig. 9F), the surface of the upper half of the left side is broken away. There are also posterior abrasions on the dorsal side. This thoracic vertebra is of usual morphology.

Two lumbar vertebral centra are also preserved. The centrum of what is probably the sixth/seventh lumbar vertebra (MB.Ma. 50479.17, Fig. 9G) has the shape of a cylinder with a flat dorsal surface. The neural arch is broken off. There is a prominent longitudinal keel ventrally. About four very small foramina are visible on the dorsal surface. The lateral sides also bear a number of small foramina. Whereas the epiphysis is more or less rounded in anterior view, the outline looks slightly dorso-ventrally compressed in posterior view. The stubs of the neural arch are situated on the anterior half of the centrum.

The eighth lumbar vertebra (MB.Ma. 50479.10, Fig. $9 \mathrm{H})$ is the posteriormost preserved centrum and, except for a small increase in length, it has the same shape and dimensions as the previously described lumbar.

In all vertebrae the epiphyses are united with the vertebral corpus. It can therefore be assumed that this individual was a fully grown animal when it died.

One isolated transverse process (MB.Ma. 50479.11, Fig. 10) was also found during the recovery of the fossil. Comparative studies indicate that it belonged to a middle thoracic vertebra. It is a left transverse process. The medio-lateral width is distinctly shorter than the antero-posterior length. The distal articulation facet for the costal tuberculum is broad with a concave depression. The interior of the bone, visible via the break on the proximal surface, exhibits widely spaced lacunae. An irregular lobe- or scar-like tuberosity which marks the origin of the levator muscles of the ribs (Mm. levatores costarum) is located on the dorsal aspect of the distal margin. The ventral aspect has a smooth surface. The distal width is $74 \mathrm{~mm}$, the dorso-ventral diameter of the transverse process measures $27 \mathrm{~mm}$.

Two pieces of ribs were also recovered. One consists of the proximal part (MB.Ma. 50479.12, Fig. 11A) with a slightly thickened capitulum and the other the distal third (MB.Ma. 50479.25, Fig. 11B) of a rib exhibiting a longitudinal edge.

Appendicular skeleton - An acromion (Fig. 12) and one phalanx (Fig. 13) are the only appendicular elements that are preserved.

Physeterid scapulae usually have an extremely well developed acromion (Benke 1993). The depth of the acromion in the Groß Pampau spe- 


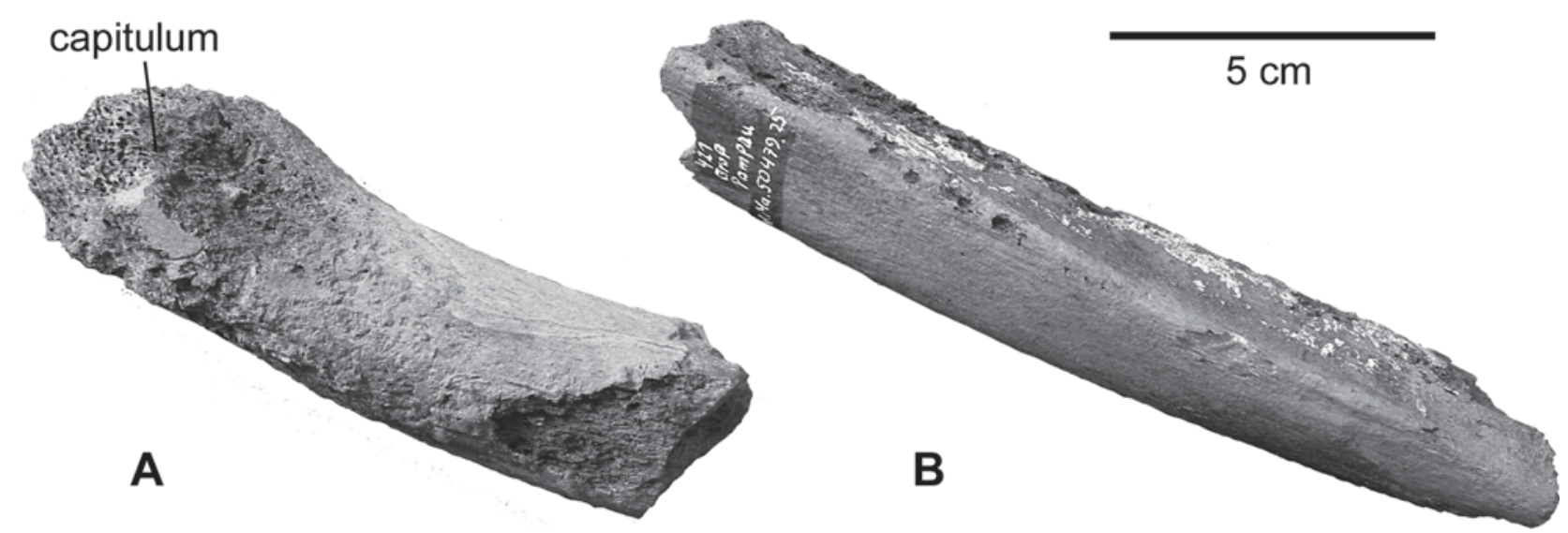

Fig. 11. Hoplocetus ritzi n. sp.: A - proximal rib fragment, MB.Ma. 50479.12, with corroded capitulum and B - a fragment of what appears to be the distal third of a rib, MB.Ma. 50479.25.

cimen (MB.Ma. 50479.13) measures $2.7 \mathrm{~cm}$. One side is heavily corroded whereas the other side has a smooth surface with delicate longitudinal grooves (Fig. 12). It is not possible to determine which side is medial and which is lateral in this fragment. Both upper and lower margins run approximately parallel to one another, one

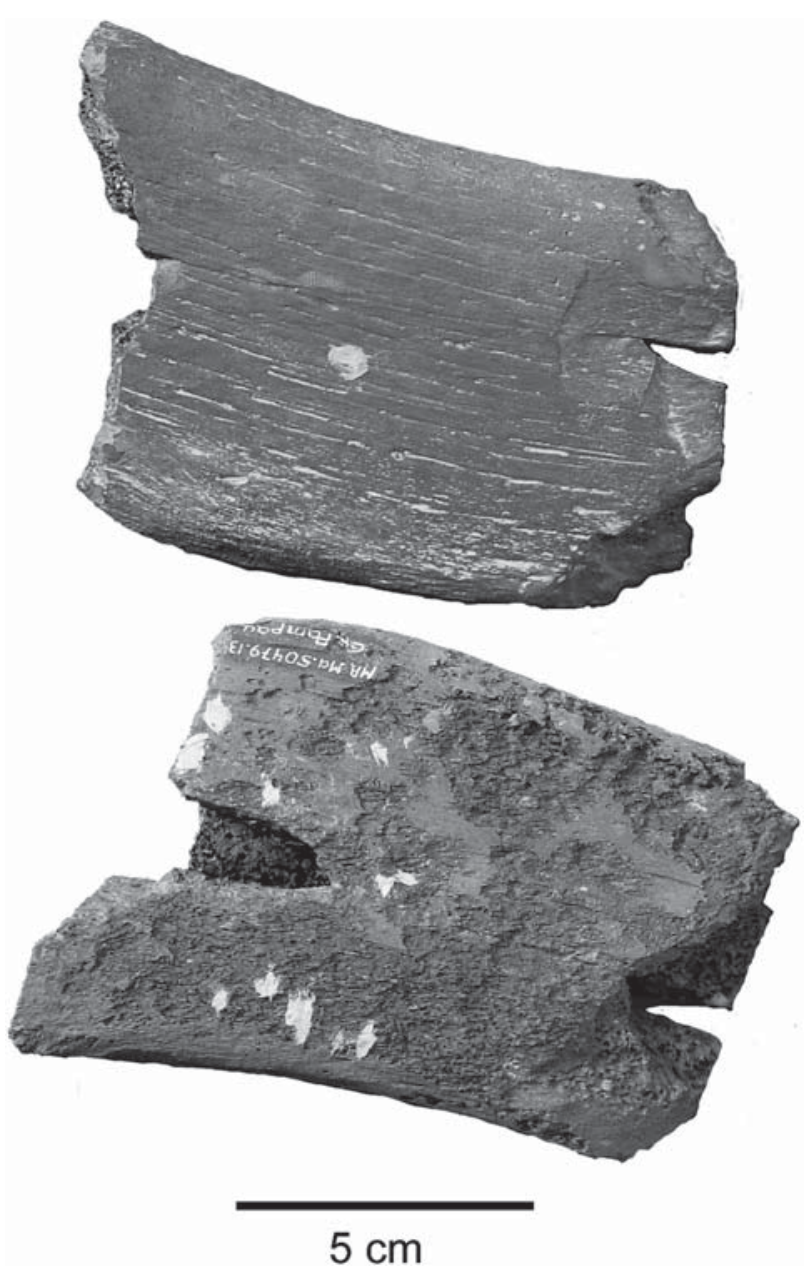

Fig. 12. Hoplocetus ritzi n. sp.: fragment of an acromion, MB.Ma. 50479.13, in lateral and medial sides. Exact orientation is unknown. slightly convex, the opposite correspondingly concave. The interior of the acromion exhibits an oval-shaped medullar cavity. The distal half of a single phalanx (MB.Ma. 50479.26) belonging to the second, third or fourth digit (based on comparison with recent Physeter macrocephalus, e.g. Flower 1868, pl. 61: fig. 1; Benke 1993, figs 21, 22 ) is preserved. The fragment has rough anterior and posterior margins and shows minute pittings on both lateral and medial aspects and a distinct tuberosity for the tendons of the flexor and extensor musculature (Mm. extensor digitorum communis et flexor digitorum communis). The phalanx has an hourglass form. The oval to drop-shaped outline of the proximal surface is uneven. The distal width is $42 \mathrm{~mm}$.

Discussion - The following considerations focus on the comparison of the teeth. The first teeth examined from Groß Pampau, originally coming from the Ritz collection, showed strong abrasions of the coronal area (MB.Ma. 50479.1-5) and had lost the enamel cap which is characteristic for primitive physeterids. Orcinus citoniensis Capellini, 1883 (MGGCB-1COC17) from the middle Pliocene of Siena Province in Tuscany, Italy, remains the only undoubted evidence of a fossil killer whale so far. Its relatively robust teeth (MGGCB-1COC11) are distinctly smaller than the Groß Pampau teeth, and have an antero-posteriorly compressed root which is also a different character to the teeth of Hoplocetus ritzi.

Hampe (1999) already mentioned that the Groß Pampau vertebrae are markedly larger than the vertebrae of the Italian Orcinus citoniensis. Vertebral centra are usually of minor value for comparative taxonomic discussions. Detailed descriptions of fossil vertebrae of physeterids remain poor. However, the vertebrae of 


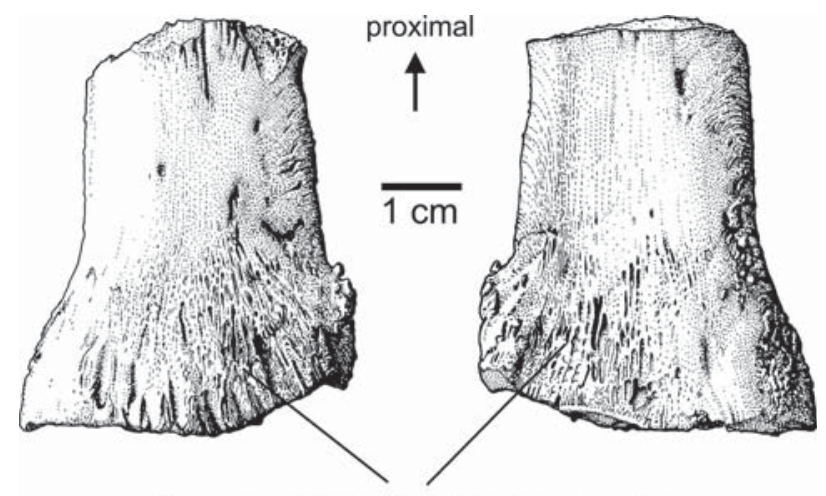

tuberosities for the tendons of flexor \& extensor muscles

Fig. 13. Hoplocetus ritzi $\mathrm{n}$. sp.: distal half of a digital phalanx, MB.Ma. 50479.26, in lateral and medial view, showing rugosities and pittings indicating the attachment areas of the musculature.

Hoplocetus ritzi are comparable with those of Physeter macrocephalus. Both species show the same trend of increase of the length of the centra (Fig. 14). Furthermore, a shorter fourth than third thoracic vertebra of Hoplocetus ritzi is also observed in the Tasmanian specimen of Physeter macrocephalus (Flower 1868). The ziphiid Ninoziphius platyrostris from the Pliocene of Peru (ziphiids form a monophyletic clade with the physeterids, Muizon 1991; Fordyce 1994) exhibits a similar trend in which the length of the vertebral centra increases. The recent delphinoid Orcinus orca, on the other hand, shows a slower increase in lengths of the vertebral centra (see interval between tenth thoracic vertebra and sixth lumbar vertebra, Fig. 14). Other characters are not comparable because of the lack of data.
Although previous workers have often regarded physeterid teeth as not significant for systematics, the following comparative discussion shows that the tooth morphology, concentrating on the characters of the holotypes, allows a revised systematic grouping of the Hoplocetinae. In the latest review of fossil sperm whales, Kazár (2002) presents a revised phylogeny of the Physeteridae and regarded the Hoplocetinae as incertae sedis, because the type species consists of just two teeth.

However, it appears that besides cranial features (e.g., low supracranial basin, lambdoid suture oriented dorso-anteriorly), the presence of robust and massive teeth and an enamel cap is typical for the representatives of the Hoplocetinae. One should keep in mind that the taxonomic proposal presented here is not a phylogenetic discussion of hoplocetines (enamel cover is recognized as a plesiomorphic character).

Generally, the problem of evaluating odontocete dentitions is that in the majority of species the teeth are strongly homodont. In addition, there are few observations of the ontogenetic development of recent physeterid teeth. Boschma (1938) gives the most comprehensive contribution to the dentition of Physeter. He demonstrated the dental variability in the living sperm whale, which is used here to determine the teeth of Hoplocetus ritzi. Also several better preserved jaws containing teeth from fossil species helped with the allocation of tooth positions (Scaldicetus shigensis, ?Idiorophus bolzanensis, Physeterula dubusi). Sexual dimorphism in the dentition is not sufficiently documented. It has happened that the sexes of stranded individuals of Physeter were left unrecorded (Ritchie \& Edwards 1913).
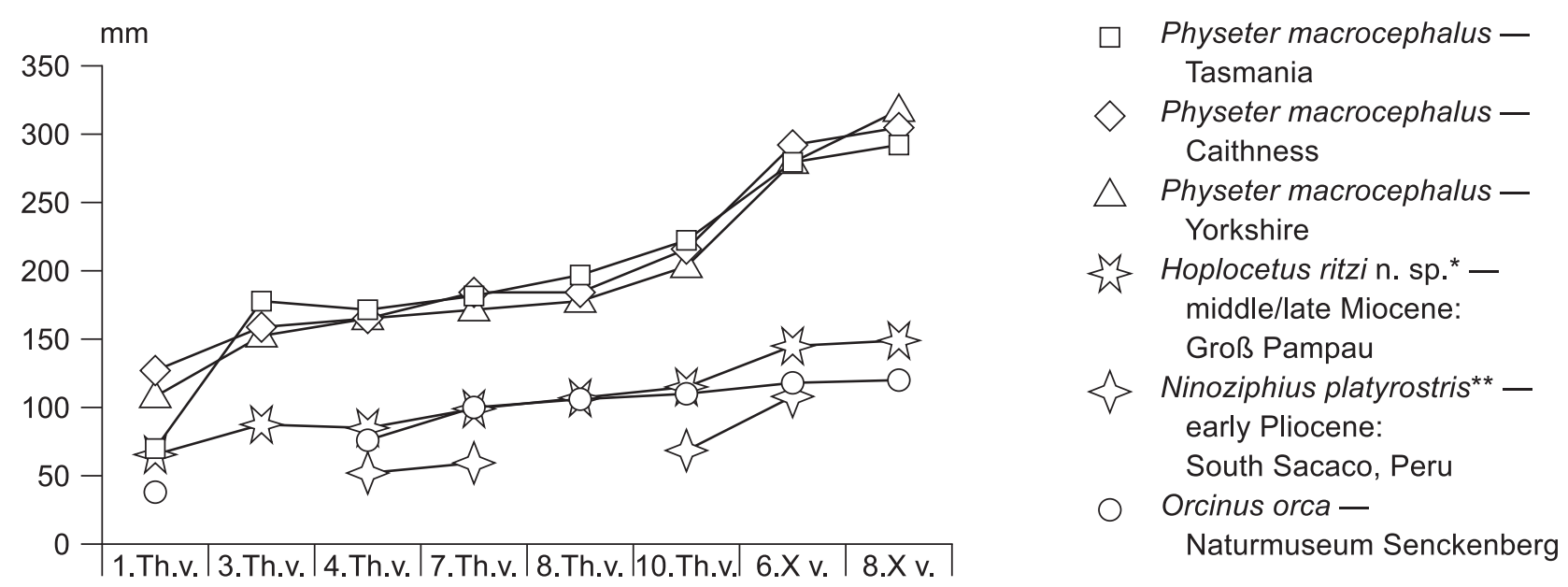

Fig. 14. Hoplocetus ritzi $\mathrm{n}$. sp.: lengths of the preserved vertebral centra* compared with measurements of vertebral centra of three individuals of Physeter macrocephalus from Flower (1868), Ninoziphius platyrostis** from Muizon (1984), and Orcinus orca (SMF 93381). ${ }^{*}$ 7. Th.v. $\Rightarrow$ measurement from 6./7. Th.v.; 6. Xv. $\Rightarrow$ measurement from 6./7. Xv.; $* *$ data for $6 . \mathrm{Xv} .=7$. lumbar of de Muizon. 
Table 3

The revised Hoplocetinae. Four genera are recognized. ?Idiorophus bolzanensis was initially described as Scaldicetus (Dal Piaz 1916). The tooth shape of ${ }^{*}$ Scaldicetus perpinguis and ${ }^{*}$ Scaldicetus inflatus is reminescent of teeth from the far end of a tooth row. eM - early Miocene; $\mathbf{e P}$ - early Pliocene; IM - late Miocene; $\mathbf{M}$ - Miocene; $\mathbf{m M ~ - ~ m i d d l e ~ M i o c e n e ; ~} \mathbf{P}$ - Pliocene.

Scaldicetus minor (Portis, 1885)

Scaldicetus macgeei Chapman, 1912

Scaldicetus grandis Du Bus, 1872

Scaldicetus mortselensis Du Bus, 1872

Scaldicetus degiorgii Varola, Landini \& Pilleri, 1988

Scaldicetus caretti Du Bus, 1867

Scaldicetus shigensis Hirota \& Barnes, 1994

* Scaldicetus inflatus Cigala-Fulgosi \& Pilleri, 1985

* Scaldicetus perpinguis Pilleri \& Pilleri, 1982

Hoplocetus ritzi $\mathrm{n}$. sp.

Hoplocetus crassidens Gervais, 1848

Hoplocetus curvidens Gervais, 1848

Hoplocetus borgerhoutensis Du Bus, 1872

Idiorophus patagonicus (Lydekker, 1893)

?Idiorophus bolzanensis (Dal Piaz, 1916)

Diaphorocetus poucheti (Moreno, 1892)

The association of dental features with taxonomically significant bone features as well as interand intraspecific variation of teeth in fossil sperm whales is still poorly known. Abel (1905b) considers several species of the Scaldicetus- and Hoplocetus-group as conspecific and interprets varied morphologies as different stages of intraspecific abrasion. This is a restricted point of view which is not accepted here.

At least one line of physeterid dental reduction through time, retaining rudimentary teeth in the maxillaries seems to be associated with a specialisation for theutovory. Clarke et al. (1988) demonstrates that in Southeast Pacific individuals the teeth are not important for feeding in the living Physeter. Holding and swallowing of squid is independent of the presence of teeth. Principally, the teeth in the sperm whales' lower jaw erupt after they reach maturity. Comparisons of the dentition of Physeter macrocephalus with the strong functional adaptations evident in the interaction between upper and lower jaw in fossil species is limited, although in the living sperm whale contact facets on dentary teeth caused by contact with reduced maxillary teeth are recorded (Boschma 1938; Keil \& Büttner 1962).

The following discussion is an attempt to throw more light on the systematics of the Hoplocetinae. Parallel development in tooth morphology related to functional adaptations of feeding can not be excluded.

The Hoplocetinae was erected by Cabrera (1926, p. 408) on the presence of a functional dentition in both the upper and lower jaw. This was later supported by Slijper (1936) who united the Tertiary physeterids "Apenophyseter" (= Idioro-

$\begin{array}{ll}\mathrm{P} & \text { Mediterranean - Tethys } \\ \mathrm{eP} & \text { South Pacific } \\ \mathrm{IM} & \text { Eastern North Atlantic } \\ \mathrm{lM} & \text { Eastern North Atlantic } \\ \mathrm{lM} & \text { Mediterranean - Tethys } \\ \mathrm{mM} & \text { Eastern North Atlantic } \\ \mathrm{mM} & \text { North Pacific } \\ \mathrm{mM} & \text { Mediterranean - Tethys } \\ \mathrm{mM} & \text { Mediterranean - Tethys } \\ \mathrm{m} / \mathrm{lM} & \text { Eastern North Atlantic } \\ \mathrm{M} & \text { Mediterranean - Tethys } \\ \mathrm{M} & \text { Mediterranean - Tethys } \\ \mathrm{M} & \text { Eastern North Atlantic } \\ \mathrm{eM} & \text { South Atlantic } \\ \mathrm{eM} & \text { Mediterranean - Tethys } \\ \mathrm{eM} & \text { South Atlantic }\end{array}$

phus), Diaphorocetus, Scaldicetus and Aulophyseter with a maxillary dentition. However, a functional dentition in the upper and lower jaw can also be observed in basal physeterines and aulophyseterines (e.g. Orycterocetus, Physeterula, Aulophyseter). The reduction of dentition in the upper jaw is a general development in stratigraphically younger physeterids, independent of their systematic position. The presence of an enamel cap, a plesiomorphic character, is not restricted to hoplocetines but also occurs in aulophyseterines. So, how should we define the Hoplocetinae? The descriptions and comparisons by Lydekker (1893), Kellogg (1925a, 1928), Hirota \& Barnes (1994), and Kazár (2002) show that the skulls of the forms allied to the Hoplocetinae in the present concept show a lower developmental stage of the supracranial basin, which is a prerequisition for the development of the cushion of liquid waxes. Furthermore, the supraoccipital shield is not positioned vertically at that stage and the dorsal lambdoid margin is oriented anteriorly. All hoplocetines have extremely robust and massive teeth in contrast to the dentition in the fossil physeterines and aulophyseterines (see below), which have relatively slender teeth. The enamel cap of the hoplocetines is shorter than that of aulophyseterines (see, e.g. Okazaki 1992, pl. 47).

Non-hoplocetine physeterids - With regard to teeth, representatives of the subfamily Physeterinae are not comparable to Hoplocetus ritzi. All fossil physeterines generally have slender teeth and lack enamel, as, for example, in Physeterula dubusi from the Miocene of Baltringen and the 
late Miocene of Antwerp, Belgium (Van Beneden 1877a, pl. I; Abel 1905a, figs 11, 12; Pilleri 1986a, pl. I: fig. 3; pl. II: figs 1, 4-7; pl. XXIII: fig. 2, pl. XXXIV: fig. 1). Teeth of Orycterocetus crocodilinus are also distinctly more slender than those of the Groß Pampau specimen. Physeterine teeth from the famous late early to early middle Miocene Calvert Formation of Maryland are very slender and pointed (e.g. "hypotype" USNM 22930). The teeth are clearly shorter than in Hoplocetus ritzi, approximately $7 \mathrm{~cm}$ in height and have no enamel cap (Kellogg 1965, pl. 30).

The type specimen of another physeterine, Placoziphius duboisi from the middle Miocene (Anversien) of Antwerp region in Belgium, has no teeth preserved (Van Beneden 1868). A few teeth were, however, found in association with another specimen from Burgenland, Austria. The teeth and tooth fragments, figured by Kazár (2002, pl. 1: fig. 4) are small, slender and heavily corroded. Kazár (2002, p. 157) suggests a minor heterodonty in height and shape.

Another group that has no close typological relationship to Hoplocetus ritzi, at least considering the teeth, are representatives of the recently defined group Aulophyseterinae (Kazár 2002). Aulophyseter morricei from the Temblor Formation (middle Miocene) of Bakersfield in Kern County, California, has teeth that average $9 \mathrm{~cm}$ in length (Kellogg 1927). The teeth of Aulophyseter morricei are smaller than those of Hoplocetus ritzi, and are flattened bucco-lingually with a hook-like crown as evident in the four holotype teeth (USNM 11230). The enamel cap is smooth anteriorly and on one of the lateral (lingual or buccal) aspects; on the opposite aspect the enamel is slightly wrinkled (Kellogg 1927, p. 16, pl. 7). Okazaki (1992, pl. 47: figs 8-10) also described relatively slender, but in part strongly curved teeth with a slightly wrinkled enamel cap of Aulophyseter sp. from the early Miocene of central Japan. The hook-like appearance of $A u$ lophyseter teeth may suggest a step toward degeneration compared with the small, often twisted maxillary teeth of the living Physeter.

The systematic position of Preaulophyseter gualichensis from the Bajo del Gualicho Formation (Neogene?) of Río Negro Province, Argentina, remains unclear. This taxon is represented by just two teeth and one periotic. The teeth are very slender, curved and gradually tapered. The enamel covered coronal area is completely rugose (Caviglia \& Jorge 1980).

Extremely slender and sometimes strongly curved teeth are known from different fossils be- longing probably to the Kogiidae. Teeth of $\mathrm{Ko}$ giopsis floridana, probably from the late Miocene (see Sellards 1915) of Polk County, Florida (Kellogg 1929, figs 1-3), and the extant species Kogia breviceps (Pilleri 1986b, pl. III) and Kogia simus (Pilleri 1986b, pl. IV) have no similarities to those of Hoplocetus ritzi. Miokogia elongatus from the early Miocene of Baltringen, Württemberg (Pilleri 1986a) and Kogia prisca from the Pleistocene of Japan (Matsumoto 1926) are considered as nomina dubia by Bianucci \& Landini (1999), but only because they are known from only a few teeth.

Thalassocetus antwerpiensis and Prophyseter dolloi from the late Miocene of Belgium and both erected by Abel (1905a), are represented by skull elements, but teeth and postcranial skeleton are not known, and for that reason these species are not comparable with Hoplocetus ritzi. Prophyseter dolloi is only known from jaw bones with empty tooth sockets (Abel 1905a, figs 13, 14).

Comparison of Hoplocetus. The teeth of Hoplocetus ritzi are most similar to those of Hoplocetus crassidens from the Miocene of Drôme, southern France (Gervais 1848-1852, pl. 20: fig. 10). The teeth of the French species are generally of the same shape, with a robust, massive root. The upper region below the gingival margin is also bulbous and the crown has a constricted collum. Differences are evident in the ornament on the surface of the enamel cap, which is completely covered with vertical striations in Hoplocetus crassidens, whereas the root has a comparatively smooth surface. A second tooth figured by Gervais $(1848-1852$, pl. 20: fig. 11$)$ is more slender than any of the teeth from Groß Pampau. Unfortunately, the holotype of Hoplocetus crassidens was based only on two isolated teeth. Gervais (1848-1852, p. 464) listed them in a section on incompletely known whales ("Sur quelques débris de Thalassothèriens incomplétement connus"). Nevertheless, the species can be considered as valid because it exhibits several distinct characters (surface of enamel cap, constricted crown). Hoplocetus curvidens was the second species erected by Gervais from the Miocene of Montpellier, the name originating from the stronger curvature of the upper crown below the enamel cap. The teeth of this species reveal no distinct differences in shape from those of $\mathrm{Ho}$ plocetus crassidens (Gervais 1848-1852, pl. 3: fig. 12; Van Beneden \& Gervais 1868-1880, pl. XX: fig. 25), but the enamel cap is thin (less 


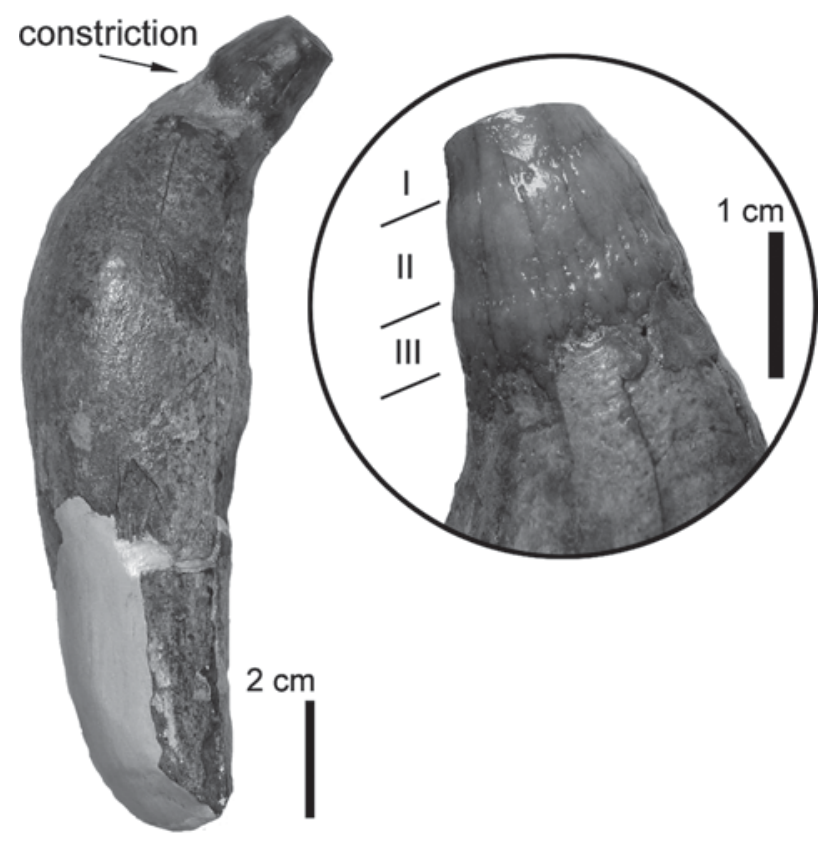

Fig. 15. Hoplocetus curvidens, MNHN RL 20, holotype, isolated tooth from the Miocene of Montpellier, France, with detail of the crown showing the tripartite enamel cap.

than $1 \mathrm{~mm}$ ) and is divided into three regions each "band" slightly decreasing in diameter: the lower band is strongly vertically striated with a wavy pattern on the antero-buccal aspect (Fig. 15). The rest of the surface of the lower band is smooth. The central band is almost smooth as is the upper band.

The vertical striations on the enamel cap of Hoplocetus borgerhoutensis from the ?Pliocene of Hérenthals, Antwerp (Van Beneden \& Gervais $1868-1880$, pl. XX: fig. 28) are rather weak. The constriction of the crown below the enamel cap is extremely well pronounced. The teeth of Hoplocetus borgerhoutensis are generally more slender than those of French species and Hoplocetus ritzi. Six highly variable teeth ("unisodonty") of this species were originally described by Du Bus (1872). Teeth from the ?Pleistocene of Suffolk, England, related to the same species are very slender and more resemble Physeterula teeth in shape, with boomerang-like outlines, tapering both toward the coronal and basal ends (e.g., BMHN 28980).

Leidy (1868) described a whale tooth from the vicinity of Charleston, South Carolina ("PostPliocene") naming it Hoplocetus obesus. According to Leidy's description this single element has the same morphology as the tooth of Hoplocetus crassidens figured by Gervais (1848-1852, pl. 20: fig. 10), but is more curved. In any case there is still doubt about the taxonomic value of the North American species. Later, Leidy (1877, pl. 6) figured two teeth from the same location as Dinoziphius carolinensis with clearly abraded enamel and a swollen upper part of the crown, but their taxonomic relationships could not be established.

Comparison of Scaldicetus. The main difference to Hoplocetus is that the teeth of species of Scaldicetus have no constriction below the enamel crown, irrespective of their ontogenetic age. Judging from the size of teeth, Scaldicetus species appear to have been giant hoplocetines.

The teeth of Scaldicetus caretti from the late Miocene of Borgerhout (Sables a'Anvers), Belgium (Van Beneden \& Gervais 1868-1880, pl. XX: fig. 24), have a rounded cross-section and generally the same habitus as Hoplocetus ritzi. Scaldicetus caretti has the largest teeth found so far of all known Hoplocetinae, with a length of 20 to $24 \mathrm{~cm}$ and a circumference of 14 to $23 \mathrm{~cm}$. With exception of the crown, all teeth of the large Belgian species are less curved and nearly straight. The enamel cap is completely covered with longitudinal striations. Du Bus (1867, p. 568) first erected Scaldicetus caretti. Abel (1905a) synonymised many taxa (a.o. Hoplocetus crassidens, Hoplocetus curvidens, and Hoplocetus borgerhoutensis) with this species. Abel's opinion cannot be supported as discussed above.

Another species from the late Miocene of Belgium (Antwerp) is Scaldicetus grandis (Abel 1905a, figs 3, 4). This taxon has banana-like teeth as Hoplocetus ritzi. However, unlike the Groß Pampau species, teeth of Scaldicetus grandis have no constricted collum and the en-

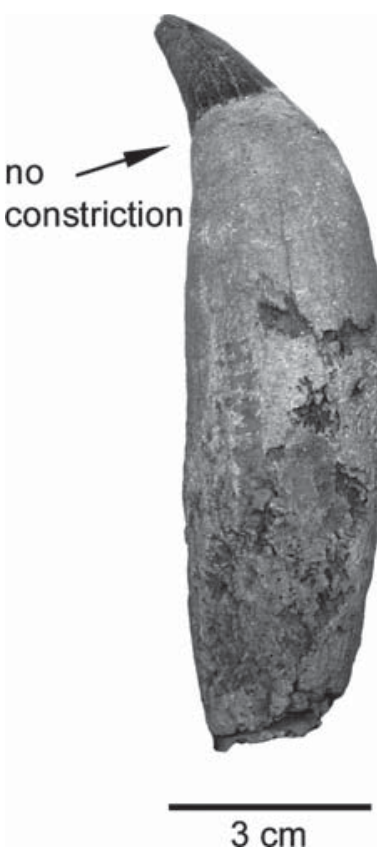

Fig. 16. Scaldicetus grandis, IRSN 518, holotype, isolated tooth from the late Miocene of Antwerp, Belgium. 
amel cap has a rugose surface similar to that of Scaldicetus caretti (Fig. 16). The root of Scaldicetus grandis tends to be bifid. Abel (1905a) considered Palaeodelphis grandis (Van Beneden \& Gervais 1868-1880, pl. XX: fig. 21) and Palaeodelphis minutus (Van Beneden \& Gervais 1868-1880, pl. XX: figs 22, 23) as conspecific with Scaldicetus grandis. Scaldicetus grandis has also been reported from the Mediterranean/ Tethys area: Pilleri (1986c, fig. 3; pl. VIII, IX) described teeth from the Tortonian of Apulia, Italy, with the same characteristics as the Belgian teeth.

A tooth of unknown geological age from Menorca, Spain, was assigned to Scaldicetus grandis by Mercadal et al. (1985, pl. I). However, the fragmentary preservation of this extremely worn specimen does not allow specific determination.

Scaldicetus degiorgii from the late Miocene of Apulia, Italy (Varola et al. 1988, figs 1-3, pl. I, II) is quite different from Hoplocetus ritzi, and also from other Scaldicetus species. The teeth of Scaldicetus degiorgii are distinctly longer than those of the Groß Pampau specimens. The root has a very prominent bulge below the crown. There is often a sharp kink in this region resulting in a $130^{\circ}$ deviation of the crown from the tooth axis. The enamel cap is completely rugose and the surface of the cementum is without any noticeable structure.

Scaldicetus mortselensis is a small representative of the genus from the late Miocene of Antwerp (Du Bus 1872 as Eudelphis mortezelensis). It is represented by an incomplete skull (Abel 1905a, fig. 5) and a few teeth that have not been figured. The teeth are short $(<9 \mathrm{~cm})$, only slightly curved and lack the constriction of the crown below the enamel cap as is characteristic for Scaldicetus. The enamel cap is clearly divided into an upper and lower region. The lower region has a larger diameter, but the structure of both regions is similar and shows a soft rugose surface.

Scaldicetus shigensis from the middle Miocene of Nagano Prefecture, Japan, is represented by a relatively completely preserved skeleton (Hirota \& Barnes 1994, figs 5-17). A wrinkled enamel cap with a somewhat crenulate sculpture and the lack of a coronal constriction distinguishes the teeth from those of the Groß Pampau species. The Japanese individual represents a fully grown specimen having teeth with a closed pulp canal. The smaller degree of wear on the crowns of Scaldicetus shigensis teeth may indicate a different manner of occlusion and/or a different diet.

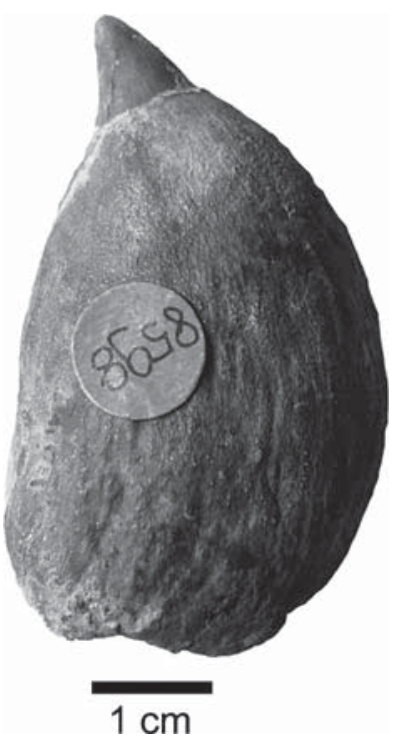

Fig. 17. Scaldicetus perpinlotype, isolated tooth from the middle Miocene of Piemonte, North Italy. guis, MGGCB-1COC52, ho-

Scaldicetus macgeei from the early Pliocene of Victoria, Australia (Chapman 1912, figs 1-3) is represented by only one tooth. It has a stout cone with an enamel cap bearing a fine rugose surface. The cap does not show any abrasive structures and there is no constriction below the cap as in the teeth of Hoplocetus ritzi. The Australian tooth gradually tapers towards the tip.

The tooth morphology of the two following species from Italy, Scaldicetus perpinguis and Scaldicetus inflatus, is unique. Scaldicetus perpinguis was collected from the middle Miocene of Piemonte (Pilleri \& Pilleri 1982, fig. 16j, pl. XVII, as Hoplocetus; Pilleri 1986c, fig. 4), and the single known tooth is comparatively short. It has a bulbous shape - the root is kiwi-fruit-shaped with little compression (Fig. 17). The tooth crown of Scaldicetus perpinguis is equipped with an enamel cap, which appears smooth, but on close examination is seen to be covered with extremely delicate striations. Although the size and proportions are quite different, the posteriormost tooth (MB.Ma. 50479.24) of Hoplocetus ritzi is most similar to the tooth of Scaldicetus perpinguis. The Italian tooth can therefore probably be interpreted as a morphological variation of a posterior tooth. Teeth of Scaldicetus inflatus from the lower Serravallian of Visiano, Parma, Emilia (Cigala-Fulgosi \& Pilleri 1985, pl. I, pl. III: fig. 16; Pilleri 1986c, fig. 2; Pilleri \& Cigala-Fulgosi 1989, fig. 8) show no similarities to the Groß Pampau teeth. They have a large, "inflated" root, the surface of which bears longitudinal grooves. The enamel cap has fine striations, and as typical for Scaldicetus, there is no constricted collum below the crown. The fossil material of both Italian 
species probably represents posterior tooth types.

Scaldicetus minor was described from the Pliocene of Astigiano, North Italy (Portis 1885, pl. VII, figs 87-90 as Hoplocetus; Pilleri 1980, pl. 19A-Da, b; Pilleri 1987, pl. XLVIII, figs 1-5, as Scaldicetus grandis). Unfortunately, the type material consists only of a single corroded tooth, two horizontal sections, and four isolated enamel caps. The complete tooth lacks a constriction below the enamel cap as is typical for Scaldicetus. The enamel caps, however, are very different from those of the new Groß Pampau species. They have a distinctive sculpture consisting of a smooth upper region and a proximal rugosity that is limited to one side of the cap, as can be observed in isolated caps (Fig. 18). The cementum of the teeth of Scaldicetus minor is relatively roughly structured (corrosion?).

"Ontocetus emmonsi" was erected by Leidy (1860) on the basis of a large, single tooth from Miocene deposits of North Carolina, but was only poorly characterised. Teeth of "Ontocetus oxymycterus" from the Helvetian of Santa Barbara, California (Kellogg 1925a, pl. 7: fig. 2, pl. 8: figs 1, 2; Kellogg 1925b, pl.2) are extremely large with a root nearly double the diameter of teeth of Hoplocetus ritzi, but they do not show any constriction below the enamel cap. Kellogg (1925a) assigned this taxon to Scaldicetus caretti.

"Eucetus amblyodon" is known from the Miocene deposits of Antwerp (Van Beneden \& Gervais $1868-1880$, pl. XX: figs 29,30 ). The teeth are heavily eroded probably owing to taphonomic processes. Abel (1905a) synonymised " $E u$ cetus amblyodon" with Scaldicetus caretti. These

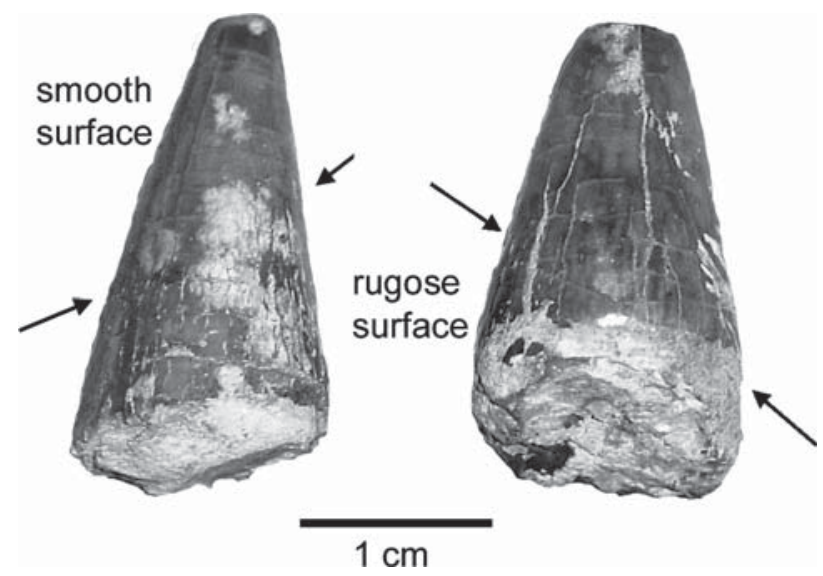

Fig. 18. Scaldicetus minor, MRSNT PU 13862/6, enamel caps of teeth from the Pliocene of Astigiano, North Italy, showing the disproportionate pattern of uneven sloping between the lower, rugose and the upper, smooth region typical of this taxon. The boundary of the structural surface pattern is indicated by arrows. teeth are distinctly greater in height and circumference and less curved than the teeth of the Groß Pampau species.

Comparison of Diaphorocetus. There are no detailed descriptions of the teeth of Diaphorocetus poucheti from the early Miocene of Chubut, Patagonia, Argentina (Moreno 1892 as "Mesocetus"; Lydekker 1893 as "Hypocetus"). The species was determined from skull characters and is the only species of the genus known so far. Kazár (2002) recognizes a closer relationship between the late Miocene Aulophyseter rionegrensis, also from Argentina (Gondar 1974) and Diaphorocetus based on the shape of the premaxillaries, the zygomatic processes, the temporal fossae, and the alveoli for the maxillary teeth. Diaphorocetus poucheti is not directly comparable with the Groß Pampau species. Although insufficiently described by Gondar (1974, pls. 1, 2), the figured teeth of Aulophyseter rionegrensis are certainly more slender than those of Hoplocetus ritzi.

Comparison of Idiorophus. Idiorophus patagonicus (Lydekker 1893, figured on p. 5, pl. II, as "Physodon"), represents another early Miocene hoplocetine known from Chubut. The teeth of Idiorophus patagonicus have a finely grooved enamel cap, which is not separated from the proximal crown by a constriction. The marked slenderness and the short size ("Orca-sized") further distinguish these teeth from those of Hoplocetus ritzi. Lydekker (1893, p. 6) defined Idiorophus patagonicus on the basis of the greater length of the tooth crown.

A slight constriction below the enamel cap is present in teeth of ?Idiorophus bolzanensis also from the early Miocene (late Aquitanian) Belluno Sandstones of middle Piave Valley, North Italy (Dal Piaz 1916, pl. I; Pilleri 1985, pl. XXXI; Pilleri 1986c, pl. X). Otherwise the teeth of this species (Fig. 19) are quite different from those of the Groß Pampau species: they are extemely slender and less curved with only a steady increase in the diameter of the root in the posterior direction of the jaw. In addition, the enamel cap is completely smooth. The holotype consists of a partial rostrum (maxillae) containing ten teeth in situ. It is important to mention that Pilleri (1985) changed the species name to "bellunensis" which, according to nomenclatural rules, is incorrect.

Undeterminable remains. Menesini \& Tavani (1968) report on several hoplocetine grade teeth 


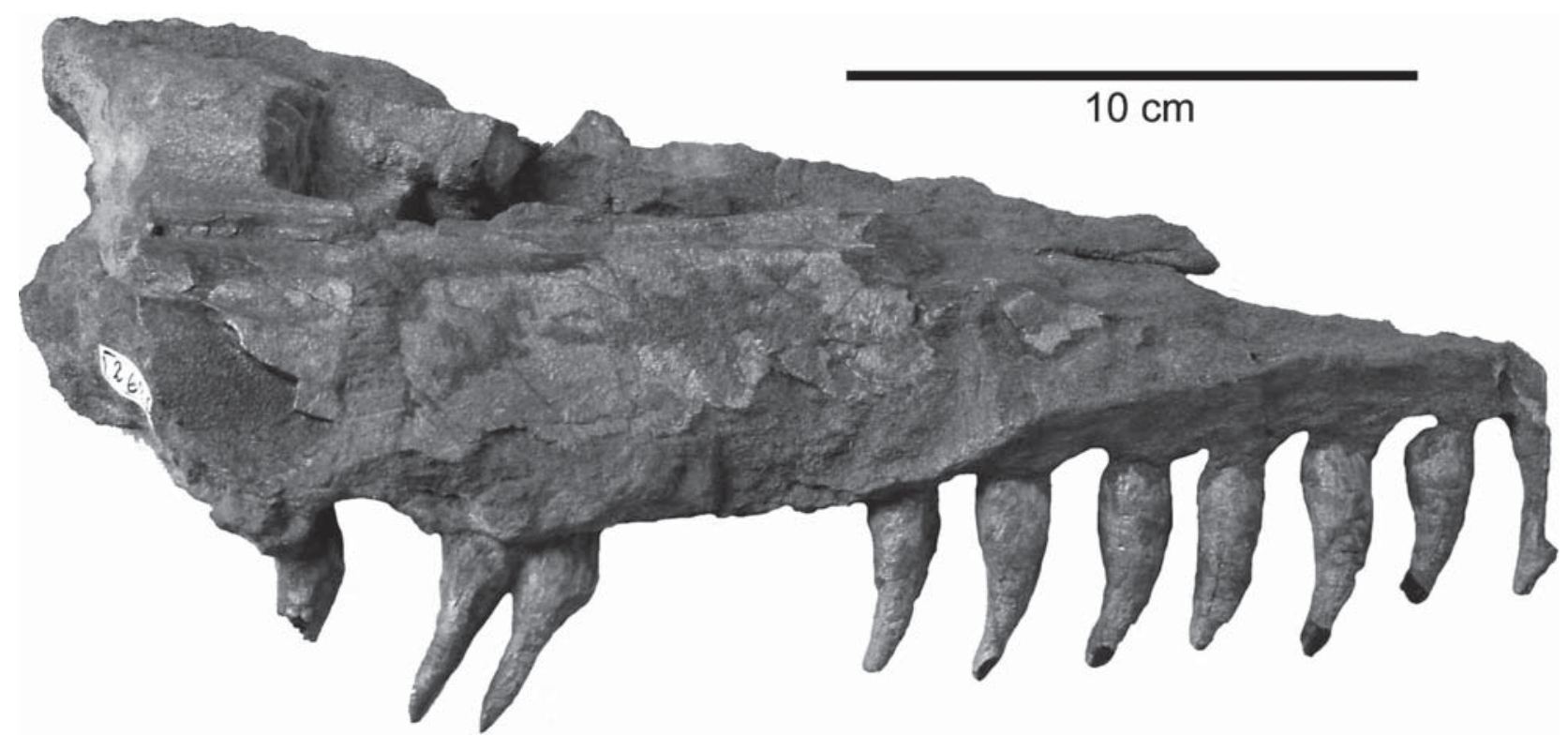

Fig. 19. ?Idiorophus bolzanensis, IMGUP N 26205, holotype, from the early Miocene of South Tyrolia, North Italy: rostrum in right dorso-lateral view with comparatively slender teeth in situ.

including "Physodon" leccense from localities around Lecce in southern Italy under the name Scaldicetus grandis. However, the validity of "Physodon" leccense (Gervais 1872) has to be considered as uncertain; the bad preservation of the teeth precludes a determination as Scaldicetus, even though the crown lacks a constriction. The teeth have slender outlines and show similarities to the tooth morphology found in Idiorophus. "Physodon" leccense is known from the early Miocene of South Italy, and the marine molasse of France, Switzerland and southern Germany. The whereabouts of the type material is unknown (Pilleri 1986d, p. 25). It is not possible, at present, to give a generic or specific characterisation. The figured teeth labeled as " $P$." leccense species differ greatly in the literature (see e.g., Van Beneden \& Gervais 1868-1880, pl. XX: figs 16-18 and Pilleri 1986d, pl. II: fig. $\mathrm{C}-\mathrm{E}$, pl. III: fig. $\mathrm{A}-\mathrm{C})$.

"Balaenodon physaloides" is reported from the Pliocene Suffolk Red Crag of England (Owen 1846, fig. 226). This taxon, based also only on teeth, has generally the same morphology, size and degree of curvature as the Groß Pampau teeth. Among the teeth several are extremely thick, and possibly from a posterior position (e.g., BMNH M 4029). These teeth are distinguished by an enamel cap completely covered with vertical cristae. Numerous teeth of this taxon were collected from the Suffolk Red Crag, but all are heavily abraded, and their surface is almost smooth and polished like that of river transported pebbles (Fig. 20). The state of pre-

servation does not permit a clear diagnosis of Owen's "Balaenodon physaloides". Owen distinguished the Red Crag specimens from the extant Physeter by the presence of a thicker cementum mantle. Similar teeth to "Balaenodon physaloides" also occur in the Phosphate Beds of Sea Island in South Carolina (e.g., USNM 6138). "Phy-

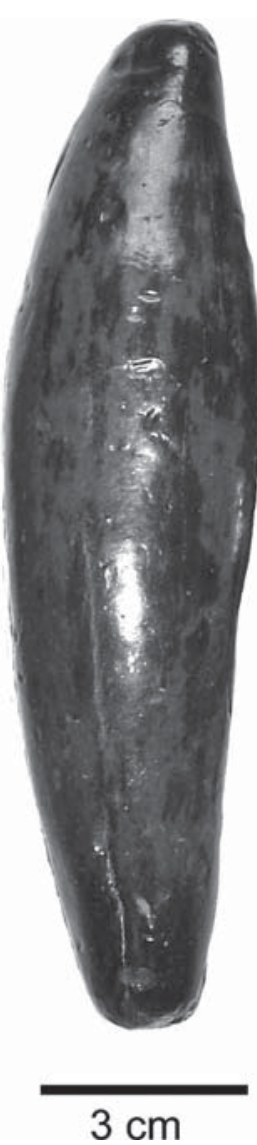

Fig. 20. "Balaenodon physaloides", BMNH M 3790, isolated tooth from the Pliocene of Suffolk, England. 
setodon baileyi" from the early Pliocene of Victoria/Australia (McCoy 1879, pl. LV: fig. 1, 2) has teeth preserved like those of Balaenodon.

"Scaldicetus" lodgei is represented by a single, very slender tooth probably of Oligocene age from Victoria, Australia (Chapman 1917, pl. IV: fig. 6). The tooth is gently curved and gradually tapers towards the apex. The enamel cap has longitudinal striations, and the root has a smooth surface. However, these characters are not sufficient to group this species within the Hoplocetinae, and its single tooth appears more like that of Physeterula.

"Scaldicetus crispus" from the lower Serravallian of Visiano in the Parma region (Cigala-Fulgosi \& Pilleri 1985, pl. II: figs 7, 8), consists of just four slightly curved root fragments with no diagnostic characteristics. "Scaldicetus crispus" is considered here as a nomen nudum.

"Helvicetus rugosus" from the Burdigalian of Switzerland is represented by a single tooth (Pilleri 1986d, pl. II: figs A, B). It is doubtful whether this specimen belongs to a physeterid at all. The same is true for "Scaptodon lodderi" from the Miocene/lower Pliocene of Tasmania (Chapman 1918, pl. XXVII). This species has slender teeth that gradually taper from base to apex, an elliptical cross-section and a crown that is not distinctly separated from the root. The tooth crowns bear sharp cutting edges, possibly serrated on the convexly curved surface. This character is not known in sperm whales.

Palaeophoca nysti, erected by Van Beneden (1859) on the basis of teeth from Belgium, is listed under the Hoplocetinae by McKenna \& Bell (1997) and as a non-diagnostic taxon of Physeteridae by Fordyce \& Muizon (2001). Kazár (2002) categorises it under Physeteridae incertae sedis. However, the Palaeophoca teeth in question do not seem to be physeterid (see Van Beneden 1877b, pl. X) but resemble the canines of pinnipeds. Koretzky (2001) strongly recommends a revision of this monachine taxon.

\section{Feeding mechanism}

In this study an attempt was made to reconstruct the dentition, with respect to establish the original position of isolated teeth. The general morphology of the teeth, their degree of curvature, the presence or absence of an enamel cap, and the position of the contact facets is utilised for this purpose. The Groß Pampau teeth are compared with published and unpublished jaw mate- rial of related fossil species (Scaldicetus) and the extant Physeter macrocephalus. Ultimately, a tentative assignment to a particular position is not possible. In addition, a rule for the intensity of functional abrasion or presence of enamel in certain jaw regions can not be established. However, it is possible to give a general orientation of the teeth (see Fig. 7) using the postero-lingual curvature (concave surface), the antero-buccal convexity and the concentration of wear on the anterior and buccal surfaces. The teeth of the living sperm whale are arranged with the concave side of the curvature oriented posteriorly. The killer whale, on the other hand, has teeth with the concave side lingually oriented.

The teeth of Hoplocetus ritzi exhibit a high degree of abrasion. The enamel cap is abraded during life by contact between the antagonistic tooth pairs. Dentine is often chipped off at a rightangle to the contact facets (MB.Ma. 50479.4, MB.Ma. 50479.21 or MB.Ma. 50479.24). The abrasive pattern of the teeth of Hoplocetus ritzi is very distinctive. It indicates the highly predatory nature of this taxon, as is also considered to be the case for other representatives of this genus. It appears to be quite similar to that observed in modern killer whales. There may possibly have been some kind of lateral and palinal movement as described for Orcinus orca (Caldwell \& Brown 1964). Considering the wear facets of the teeth, Hoplocetus perhaps occupies an ecological niche similar to that of the extant killer whale, but before the latter appeared. Nevertheless, there is no evidence that there is other than teuthophagic specialisation of diet in the fossil sperm whales. The prey preferences of Orcinus orca correspond to their geographical location and range from fish to sea turtles, birds, and marine mammals (Berta \& Sumich 1999; Ford 2002).

The Orcininae occur late in earth's history and are not known before the middle Pliocene (see above: Orcinus citoniensis), while the Hoplocetinae disappear during the Pliocene.

\section{Conclusions}

Comparative studies permit an emended diagnosis to be established for the Hoplocetinae. The new definition is based on the arrangement of skull bones (genera: Diaphorocetus, Idiorophus, Scaldicetus) and tooth morphology (genera: Idiorophus, Scaldicetus, Hoplocetus). The cranial elements form a supracranial basin of low de- 
gree; the supraoccipital is obliquely truncated, not vertically positioned, and has an anterodorsally oriented lambdoid suture. The teeth generally have robust and massive proportions and the tooth crown is equipped with a short enamel cap.

The genus Hoplocetus is diagnosed by the constriction of the crown ("neck") below the enamel cap. Species determinations are based on the different surface patterns of the enamel cap. The taxonomic approach of Abel (1905a, b) is different and not convincing. He considered many species of the Scaldicetus- and Hoplocetus-group as conspecific and interpreted different morphologies as different stages of abrasion within a single species.

The locality of Groß Pampau in SchleswigHolstein has yielded fossil material representing a new species, Hoplocetus ritzi n. sp., consisting of teeth, vertebrae and bone fragments (ribs, flipper elements) from a scattered skeleton. The age of the finds is middle/late Miocene (upper Langenfeldian in local stage), Bolboforma fragori/subfragoris Zone. The diagnostic character of this species is an enamel cap with a rugose proximal half and a smooth distal surface.

The Miocene taxa Hoplocetus crassidens and Hoplocetus curvidens from southern France (Tethys region) show the closest morphological relationship to the new North German species Hoplocetus ritzi $\mathrm{n}$. sp.

The abrasional pattern of the teeth of Hoplocetus ritzi $\mathrm{n}$. sp. indicates a highly predatory nature for this whale, comparable to that observed in recent killer whales. It can be assumed that Hoplocetus probably filled a habitat and ecological niche that is today occupied by Orcinus.

\section{Acknowledgements}

I am indebted to the private collectors Reiner Ritz (Henstedt-Ulzburg), Werner Müller and Wiena Sierk (Hamburg), Lars-Rasmus Witteck (Oststeinbek), and Hans-Jürgen Lierl (Linau) for providing the entire material and making the donation to the Museum für Naturkunde in Berlin. Many thanks go to Hans-Hartmut Krueger for additional preparation and to Jörg-Peter Mendau, Jan Müller-Edzards, and Elke Siebert (all Berlin) for several illustrations. I am very grateful to the following persons who permitted comparative studies of material in their collections: Detlef Willborn (Berlin), Wolfram Eckloff and Susanne Füting (Lübeck), Joseph Boscheinen (Düsseldorf), Gerhard Storch (Frankfurt a.M.), Elmar Heizmann (Stuttgart), Olivier Lambert and Etienne Steurbaut (Brussels), Christian de Muizon (Paris), Jeremy Hooker (London), Carlo Sarti (Bologna), Elisabetta Cioppi and Fabio Cozzini (Florence), Mariagabriella Fornasiero and Letizia Del Favero (Padova), Walter Landini and Michelangelo Bisconti (Pisa), Franca Campanino and Daniele Ormez- zano (Turin), Emese Kazár and László Kordos (Budapest), David Bohaska (Washington, D.C.), Ted Daeschler (Philadelphia), and Stephen Godfrey (Solomons, Maryland). I had useful and fruitful discussions with Wolf-Dieter Heinrich and Hans-Peter Schultze (Berlin, Lawrence), Karl Gürs (Kiel/ Flintbek), Christian de Muizon (Paris), Emese Kazár (Budapest), and Mark D. Uhen (Bloomfield Hills). David M. Unwin (Berlin) kindly approved the English. I record my grateful thanks to Ella Hoch (Gram, Denmark), Emese Kazár (Budapest), and Hans-Peter Schultze for their critical and inspiring reviews. The study was supported by the Deutsche Forschungsgemeinschaft (Ha 1776/7-1).

\section{References}

Abel, O. 1905a. Les Odontocètes du Boldérien (Miocène Supérieur d'Anvers). - Mémoires du Musée Royal d'Histoire Naturelle de Belgique 3: 1-155.

- 1905b. Die phylogenetische Entwicklung des Cetaceengebisses und die systematische Stellung der Physeteriden. Verhandlungen der Deutschen Zoologischen Gesellschaft 15: $84-96$.

Allen, G. M. 1921. Fossil cetaceans from the Florida Phosphate beds. - Journal of Mammalogy 2: 144-159.

Ameghino, F. 1894. Enumération synoptique des espèces de mammifères fossiles des formations éocènes de Patagonie. - Obas completas y correspondencia científica de Florentino Ameghino 10. Mamíferos fósiles de Patagonia y otras cuestiones, 593-855.

Barnes, L. G. 1990. The fossil record and evolutionary relationships of the genus Tursiops. In Leatherwood, S. (ed.): The bottlenose dolphin: 3-26, Academic Press, San Diego.

Behrmann, G. 1995. Der Bartenwal aus dem Miozän von Gr.-Pampau (Schleswig-Holstein). - Geschiebekunde aktuell 11 (4): 119-126.

Benke, H. 1993. Investigations on the osteology and the functional morphology of the flipper of whales and dolphins (Cetacea). - Investigations on Cetacea 24: 9-252.

Berta, A. \& Sumich, J. L. 1999. Marine mammals: Evolutionary biology. 494 pp., Academic Press, San Diego.

Bianucci, G. \& Landini, W. 1999. Kogia pusilla from the Middle Pliocene of Tuscany (Italy) and a phylogenetic analysis of the family Kogiidae (Odontoceti, Cetacea). - Rivista Italiana di Paleontologia e Stratigraphia 105 (3): 445-453.

Böckh, H. 1899. Orca semseyi, eine neue Orca-Art aus dem unteren Miozæn von Salgótarján. - Mittheilungen aus dem Jahrbuch der Königlich Ungarischen Geologischen Anstalt 13: 104-107.

Boschma, H. 1938. On the teeth and some other particulars of the sperm whale (Physeter macrocephalus L.). - Temminckia 3: $151-278$.

Brisson, A. D. 1762. Regnum animale in Classes IX. distributum, sive Synopsis methodica sistens generalem Animalium distributionem in Classes IX, \& duarum primarum Classicum, Quadrupedum scilicet \& Cetaceorum, particularem divisionem in Ordines, Sectiones, Genera \& Species. - 296 pp., Haak, Leiden.

Cabrera, A. 1926. Cetáceos fósiles del Museo de La Plata. Revista del Museo de La Plata 29: 363-411.

Caldwell, D. K. \& Brown, D. H. 1964. Tooth wear as a correlate of described feeding behaviour by the killer whale, with notes on a captive specimen. - Bulletin of the Southern California Academy of Sciences 63 (3): 128-140.

Capellini, G. 1883. Di un'Orca fossile scoperta a Cetona in Toscana. - Memorie dell'Accademia delle Scienze dell'Istituto di Bologna, Serie IV 4: 665-687. 
Case, E. C. 1904. Systematic paleontology of the Miocene deposits of Maryland. Vertebrata. Class Mammalia. In Clark, W. B. (ed.): Miocene: 3-58, Maryland Geological Survey, Baltimore.

Caviglia, S. E. \& Jorge, R. E. 1980. Preaulophyseter gualichensis Gen. et sp. nov. (Cetacea; Physeteridae), en el Terciario marino de Rio Negro, Republica Argentina. Actas del Segundo Congreso Argentino de Paleontología y Bioestratigrafía y Primer Congreso Latinoamericano de Paleontología 3: 363-370.

Chapman, F. 1912. On the occurrence of Scaldicetus in Victoria. - Records of the Geological Survey of Victoria 3 (2): 236-238.

- 1917. New or little-known Victorain fossils in the National Museum. Part XXI. Some Tertiary cetacean remains. Proceedings of the Royal Society of Victoria 30 (1): 32-43.

- 1918. On an apparently new type of cetacean tooth from the Tertiary of Tasmania. - Proceedings of the Royal Society of Victoria 30 (2): 149-152.

Clarke, R., Paliza, O. \& Aguayo, A. 1988. Sperm whales of the southeast Pacific. Part IV: Fatness, food and feeding. - Investigations on Cetacea 21: 53-195.

Cigala-Fulgosi, F. \& Pilleri, G. 1985. The lower Serravallian cetacean fauna of Visiano (Northern Apennines, Parma, Italy). - Investigations on Cetacea 17: 55-113.

Cope, E. D. 1895. Fourth contribution to the marine fauna of the Miocene period of the United States. - Proceedings of the American Philosophical Society 34 (147): 135-155.

Dal Piaz, G. 1916. Gli Odontoceti del Miocene Bellunense. Parte Nona - Scaldicetus bolzanensis. - Memorie dell'Istituto Geologico della Università di Padova 4: 87-92.

De Smet, W. M. A. 1977. The regions of the Cetacean vertebral column. In Harrison, R. J. (ed.): Functional anatomy of the marine mammals 3: 59-80, Academic Press, London.

Du Bus, B. 1867. Sur quelques Mammifères du crag d'Anvers. - Bulletins de l'Académie Royale des Sciences, des Lettres et des Beaux-Arts de Belgique, $2^{\text {me }}$ Série 24: 562-577.

- 1872. Mammifères nouveaux du crag d'Anvers. - Bulletins de l'Académie Royale des Sciences, des Lettres et des Beaux-Arts de Belgique, $2^{\text {me }}$ Série 34: 491-509.

Flower, W. H. 1867. Description of the skeleton of Inia geoffrensis and of the skull of Pontoporia blainvillii, with remarks on the systematic position of these animals in the order Cetacea. - Transactions of the Zoological Society of London 6 (3): 87-116.

- 1868. On the ostelogy of the cachelot or sperm-whale (Physeter macrocephalus). - Transactions of the Zoological Society of London 6 (6): 309-372.

Ford, J. K. B. 2002. Killer whale Orcinus orca. In Perrin, W. F., Würsig, B. \& Thewissen, J. G. M. (eds.): Encyclopedia of marine mammals: 669-676, Academic Press, San Diego.

Fordyce, R. E. 1994. Waipatia maerewhenua, new genus and new species (Waipatiidae, new family), an archaic late Oligocene dolphin (Cetacea: Odontoceti: Platanistoidea) from New Zealand. - In Berta, A. \& Deméré, T. A. (eds.): Contributions in Marine Mammal Paleontology honoring Frank C. Whitmore, Jr. - Proceedings of the San Diego Society of Natural History, 29: 147-176.

Fordyce, R. E. \& Muizon, C. de 2001. Evolutionary history of cetaceans: a review. In Mazin, J.-M. \& Buffrénil, V. de (eds.): Secondary adaptation of tetrapods to life in water: 169-233, Pfeil, Munich.

Gatesy, J. 1998. Molecular evidence for the phylogenetic affinities of Cetacea. In Thewissen, J. G. M. (ed.): The emergence of whales. Evolutionary patterns in the origin of Cetacea: 63-111, Plenum Press, New York.

Gervais, P. 1848-1852. Zoologie et Paléontologie Françaises (Animaux Vertébrés) ou nouvelles recherches sur les animaux vivants et fossiles de la France, Tome 1-3. 271 pp., Bertrand, Paris
- 1872. Coup d'œil sur les Mammifères fossiles de l'Italie. - Bulletin de la Société Géologique de France, $2^{\text {me }}$ série 29: $92-102$.

Gondar, D. 1974. La presencia de Cetaceos Physeteridae en el Terciario Superior ("Rionegrense") de la Provincia de Rio Negro. - Actas del Primer Congreso Argentino de Paleontología y Bioestratigrafía 2: 349-356.

Gottfried, M. D., Bohaska, D. J. \& Whitmore, F. C. jr. 1994. Miocene cetaceans of the Chesapeake Group. - In Berta, A. \& Deméré, T. A. (eds.): Contributions in Marine Mammal Paleontology honoring Frank C. Whitmore, Jr. - Proceedings of the San Diego Society of Natural History 29: $229-238$.

Gray, J. E. 1821. On the natural arrangement of vertebrose animals. - The London medical repository 15 (1): 296-310.

Gripp, K. 1964. Erdgeschichte von Schleswig-Holstein. 411 pp., Wachholtz, Neumünster.

Gürs, K. \& Spiegler, D. 1999. Regional Neogene North Sea Basin stages (Langenfeldian). - Aardkundige Mededelingen 11: $21-24$.

Hampe, O. 1999. Bestandsaufnahme der Walfauna (Mammalia: Cetacea) aus dem untersten Obermiozän (oberes Langenfeldium) von Groß Pampau (Schleswig-Holstein). - Berichte des Vereins "Natur und Heimat" und des Naturhistorischen Museums zu Lübeck 25/26: 87-107.

Heyning, J. E. 1989. Comparative facial anatomy of beaked whales (Ziphiidae) and the systematic revision among the families of extant Odontoceti. - Contributions in Science 405: $1-64$.

Hinsch, W. 1972. Mollusken-Biostratigraphie des Miozäns und Chatts im Südteil des Kreises Herzogtum Lauenburg (Schleswig-Holstein). - Meyniana 22: 63-70.

- 1974. Das Tertiär im Untergrund von Schleswig-Holstein (Das Nordwestdeutsche Tertiärbecken, Beitrag Nr. 5). Geologisches Jahrbuch A 24: 1-34.

- 1986. Der Leitwert miozäner Molluskenfaunen im Nordseebecken. In Tobien, H. (coord.): Nordwestdeutschland im Tertiär. - Beiträge zur Regionalen Geologie der Erde 18: $342-369$.

- 1990. Biostratigraphy of Reinbekian/Levensauian/Lüneburgian/Langenfeldian boundary stratotypes in Pampau area (SE-Holstein). - Veröffentlichungen aus dem Übersee-Museum Bremen Reihe A 10: 55-79.

Hirota, K. \& Barnes, L. G. 1994. A new species of Middle Miocene sperm whale of the genus Scaldicetus (Cetacea; Physeteridae) from Shiga-mura, Japan. - The Island Arc 3 (4): 453-472.

Höpfner, G. 1991. Wale und Haie - aus der Urzeit aufgetaucht. - Zeitschrift für Natur und Landeskunde von Schleswig-Holstein und Hamburg 98 (10/11): 245-253.

Huuse, M. 2002. Late Cenozoic palaeogeography of the eastern North Sea Basin: climatic vs tectonic forcing of basin margin uplift and deltaic progradation. - Bulletin of the Geological Society of Denmark 49 (2): 145-169.

Kazár, E. 2002. Revised phylogeny of the Physeteridae (Mammalia: Cetacea) in the light of Placoziphius Van Beneden, 1869 and Aulophyseter Kellogg, 1927. - Bulletin de 1'Institut Royal des Sciences Naturelles de Belgique - Sciences de la Terre 72: 151-170.

- 2003. Miocén fogascet-leletek (Cetacea: Odontoceti) a Kárpát-medencében. - 344 pp., Eötvös Loránd University, Budapest (unpublished Ph.D. thesis)

Keil, A. \& Büttner, W. 1962. Untersuchungen an Zähnen des Pottwales (Physeter macrocephalus L.). - Sitzungsberichte der Gesellschaft Naturforschender Freunde zu Berlin (N. F.) 2 (3): 109-119.

Kellogg, R. 1925a. Two fossil physeteroid whales from California. In Kellogg, R. (ed.): Additions to the Tertiary history of the pelagic mammals on the Pacific coast of North America. - Contributions to Palaeontology from the Carnegie Institution of Washington 348: 1-34. 
Kellogg, R. 1925b. A fossil physeteroid cetacean from Santa Barbara County, California. - Proceedings of the U.S. National Museum 66 (27): 1-8.

- 1927. Study of the skull of a fossil sperm-whale from the Temblor Miocene of Southern California. In Kellogg, R., Merriam, J. C., Stock, C., Chaney, R. W. \& Mason, H. L. (eds.): Additions to the palaeontology of the Pacific coast and Great Basin regions of North America. - Contributions to Palaeontology from the Carnegie Institution of Washington 346: 3-24.

- 1928. The history of whales - their adaption to life in the water. Part II. - The Quarterly Review of Biology 3 (2): 174-208.

- 1929. A new fossil toothed whale from Florida. - American Museum Novitates 389: 1-10.

- 1931. Pelagic mammals from the Temblor Formation of the Kern River region, California. - Proceedings of the California Academy of Science, 4th series 21 (12): 217-397.

- 1965. The Miocene Calvert sperm whale Orycterocetus. U.S. National Museum Bulletin 247 (2): 47-63.

Koretsky, I. A. 2001. Morphology and systematics of Miocene Phocinae (Mammalia: Carnivora) from Paratethys and the North Atlantic region. - Geologica Hungarica Series Palaeontologica 54: 3-109.

Leidy, J. 1860. The Dromatherium sylvestre Emmons, from the coal of Chatham Co. - Proceedings of the Academy of Natural Sciences of Philadelphia 1859: 162.

- 1868. Notice of some extinct cetaceans. - Proceedings of the Academy of Natural Sciences of Philadelphia 1868 (3): 196-197.

- 1877. Description of vertebrate remains, chiefly from the Phosphate Beds of South Carolina. - Journal of the Academy of Natural Sciences of Philadelphia, New Series, 8 (3): 209-261.

Lierl, H.-J. 1995. Ein miozäner Robbenrest (Hüftbein von Phoca sp.) aus dem Geschiebe von Groß Pampau (Kreis Herzogtum Lauenburg). - Geschiebekunde aktuell $11(1): 3-10$.

Linné, C. 1758. Systema naturae per Regna tria naturae, secundum Classes, Ordines, Genera, Species, cum Characteribus, Differentiis, Synonymis, Locis. Tomus I. Editio Decima, Reformata. - 824 pp., Laurentii Salvii, Stockholm.

Lourens, L., Hilgen, F., Shackleton, N. J., Laskar, J. \& Wilson, D. 2004. The Neogene period. - In Gradstein, F. M., Ogg, J. G. \& Smith, A. G. (eds.): A geologic time scale: 409-440, University Press, Cambridge.

Lydekker, R. 1893. Contributions to a knowledge of the fossil vertebrates of Argentina 2. Cetacean skulls from Patagonia. - Anales del Museo de La Plata, Paleontología Argentina 2: 1-13.

Matsumoto, H. 1926. On some fossil cetaceans of Japan. The Science Reports of the Tôhoku Imperial University, Sendai, Japan, $2^{\text {nd }}$ Series (Geology) 10 (1): 17-27.

McCoy, F. 1879. Physetodon baileyi (McCoy). - Prodomus of the Palæontology of Victoria; or, figures and descriptions of the Victorian organic remains 6: 19-20.

Mchedlidze, G. A. 1984. General features of the paleobiological evolution of Cetacea. - 139 pp., Amerind Publishing, New Dehli.

McKenna, M. C. \& Bell, S. K. 1997. Classification of mammals above the species level. - 631 pp., Columbia University Press, New York.

Menesini, E. \& Tavani, G. 1968. Resti de Scaldicetus (Cetacea) nel Miocene della Puglia. - Bolletino della Società Paleontologica Italiana 7 (2): 87-93.

Mercadal, B., Pilleri, G. \& Casinos, A. 1985. A tooth of Scaldicetus grandis (Du Bus, 1872) (Physeteridae) from Aire Island (Menorca, Spain). - Investigations on Cetacea 17: 31-34.

Moreno, F. P. 1892. Noticias sobre algunos cetáceos fósiles y actuales de la República Argentina conservados en el
Museo de La Plata. - Revista del Museo de La Plata 3: 383-400.

Moths, H. 1989. Die Molluskenfauna des miozänen Glimmertons aus Gross Pampau (Krs. Hzgt. Lauenburg, BRD). Der Geschiebesammler 22 (3-4): 105-162.

- 1990. Die tertiären Mollusken aus den eiszeitlichen Kiesen der Grube A. Ohle, Groß Pampau, Krs. Hzgt. Lauenburg. - Der Geschiebesammler 24 (1-2): 13-56.

- 1992. Neue Mollusken aus dem obermiozänen Glimmerton von Groß Pampau nebst einigen beobachteten Besonderheiten. - Der Geschiebesammler 25 (3-4): 91-112.

- 1998. Die Hai- und Rochenfauna aus dem Miozän (Langenfeldium) von Groß Pampau. - Der Geschiebsammler 31 (2): $51-113$.

Moths, H. \& Höpfner, G. 1993. Ältester Nachweis des Rauhzahndelphines Steno sp. im Glimmerton des Langenfeldiums (Obermiozän) von Groß Pampau. - Der Geschiebesammler 26 (4): 151-160.

Muizon, C. de 1984. Les vertébrés fossiles de la formation Pisco (Perou) II. Deuxième partie: Les Odontocètes (Cetacea, Mammalia) du Pliocène Inférieur de Sud-Saco. - Institut Français d'Études Andines Mémoire 50: $1-183$.

- 1991. A new Ziphiidae (Cetacea) from the Early Miocene of Washington State (USA) and phylogenetic analysis of the major groups of odontocetes. - Bulletin du Muséum National d'Histoire Naturelle Section C: Sciences de la Terre, Paléontologie, Géologie, Minéralogie, $4^{\mathrm{e}}$ Série 12 (3-4): 279-326.

Okazaki, Y. 1992. An occurrence of a sperm whale from the Miocene Mizunami Group, central Japan. - Bulletin of the Mizunami Fossil Museum 19: 295-299.

Owen, R. 1846. A history of British fossil mammals, and birds. - 560 pp., Van Voorst, London.

Pilleri, G. 1980. The fossil odontocetes (Cetacea) in the Museum of Paleontology of the University of Turin. - Investigations on Cetacea 11: 39-53.

- 1985. The Miocene Cetacea of the Belluno Sandstones (eastern southern Alps). - Memorie di Scienze Geologiche 37: 1-250.

- 1986a. The Cetacea of the Western Paratethys (Upper Marine Molasse of Baltringen). - 70 pp., Brain Anatomy Institute, Berne.

- 1986b. Pygmy sperm whales (Kogia) in the Italian Pliocene. - Investigations on Cetacea 18: 133-153.

- 1986c. The Oligo-Miocene Cetacea of the Italian waters with a bibliography of the fossil Cetacea of Italy (1670-1986). - 81 pp., Brain Anatomy Institute, Berne.

- 1986d. The Denticeti of the western Paratethys (upper Marine Molasse of Switzerland). - Investigations on Cetacea 19: 11-111.

- 1987. The Cetacea of the Italian Pliocene. - 160 pp., Brain Anatomy Institute, Berne.

Pilleri, G. \& Cigala-Fulgosi, F. 1989. Additional observations on the lower Serravallian marine mammals fauna of Visiano and the Stirone River (Northern Apennines). - In Pilleri, G. (ed.): Contributions to the paleontology of some Tethyan Cetacea and Sirenia (Mammalia) II.: 63-85, Brain Anatomy Institute, Ostermundingen, Switzerland.

Pilleri, G. \& Pilleri, O. 1982. Catalogue of the fossil odontocetes (Cetacea) in the Bologna Giovanni Capellini Museum of Palaeontology with description of a new species of Hoplocetus (Physeteridae). - Memorie di Scienze Geologiche 35: 293-317.

Portis, A. 1885. Catalogo descrittivo dei Talassoterii rinvenuti nei terreni terziarii del Piemonte a della Ligura. Memorie della Reale Accademia delle Scienze di Torino, Serie II 37: 247-365.

Ritchie, J. \& Edwards, A. J. H. 1913. On the occurrence of functional teeth in the upper jaw of the sperm whale. Proceedings of the Royal Society of Edinburgh 33: $166-168$. 
Ritz, R. \& Müller, W. 1998. Pott- oder Schwertwal? Sensationeller Fund in Groß Pampau. - Fossilien 1998 (1): $19-21$.

Sellards, E. H. 1915. The pebble phosphates of Florida. Florida Geological Survey Annual Report 7: 26-116.

Slijper, E. J. 1936. Die Cetaceen. Vergleichend-anatomisch und systematisch. - Capita Zoologica 6/7: 1-590.

Smith, A. G., Smith, D. G. \& Funnell, B. M. 1994. Atlas of Mesozoic and Cenozoic Coastlines. - 99 pp., Univ. Press, Cambridge.

Spaeth, C. \& Lehmann, U. 1992a. Über Bartenwale im nordwesteuropäischen Tertiär, Teil 1. - Fossilien 1992 (1): $13-23$.

- 1992b. Über Bartenwale im nordwesteuropäischen Tertiär, Teil 2. - Fossilien 1992 (2): 81-91.

Spezzaferri, S. \& Rögl, F. 2004. Bolboforma (Phytoplankton Incertae Sedis), Bachmayerella and other Calciodinelloidea (Phytoplankton) from the Middle Miocene of the Alpine-Carpathian Foredeep (Central Paratethys). - Journal of Micropalaeontology 23 (2): 139-152.

Spiegler, D. \& Gürs, K. 1996. Der miozäne Glimmerton von Groß Pampau, Schleswig-Holstein (Mollusken, Foraminiferen und Bolboformen). - Meyniana 48: 135-164.

Van Beneden, P. J. 1859. Ossements fossiles venaient d'être découverts à Saint-Nicholas. - Bulletins de l'Académie
Royale des Sciences, des Lettres et des Beaux-Arts de Belgique, $2^{\text {me }}$ sér. 8: 123-146.

- 1868. Sur un nouveau genre de ziphiode fossile (Placoziphius), trouvé a Edeghem, près d'Anvers. - Mémoires de l'Académie Royale des Sciences, des Lettres et des Beaux-Arts de Belgique 37: 1-13.

- 1877a. Note sur un cachalot nain du Crag d'Anvers (Physeterula dubusii). - Bulletins de l'Académie Royale des Sciences, des Lettres et des Beaux-Arts de Belgique, $2^{\text {me }}$ sér. 44 (12): 851-856.

- 1877b. Description des ossements fossiles des environs d'Anvers. Première Partie. Pinnipèdes ou Amphithériens. - Annales du Musée Royal d'Histoire Naturelle de Belgique 1: $1-88$.

Van Beneden, P. J. \& Gervais, P. 1868-1880. Ostéographie des Cétacés vivants et fossiles comprenant la description et l'Iconographie du squelette et du système dentaire de ces animaux ainsi que des documents relatifs a leur histoire naturelle. - 634 pp., Bertrand, Paris.

Varola, A., Landini, W. \& Pilleri, G. 1988. A new Scaldicetus (Cetacea: Physeteridae) from the Pietra Leccese, Late Miocene. - Investigations on Cetacea 21: 16-38.

Ziegler, P. A. 1990. Geological atlas of western and central Europe. - 239 pp., Shell Int. Petrol. Maat. B. V., Mijdrecht. 